\title{
TÜRK HUKUKUNUN BİR PARÇASI OLARAK AVRUPA KONSEYİ İNSAN HAKLARI ve BIYYOTIP SÖZLEŞMESI
}

\author{
European Convention on Human Rights and Biomedicine \\ as a part of Turkish Law
}

Tuğrul KATO $\breve{G} L U^{*}$

Profesör Dr. Sinan BEKSAÇ'a

\section{Giriş}

Avrupa Konseyi Parlamenterler Meclisi’nin, bir biyoetik sözleşmesi hazırlanmasına ilişkin 1160 (1991) sayılı Tavsiye Kararı doğrultusunda hazırlanan "Biyoloji ve Tibbın Uygulanması Bakımından İnsan Hakları ve İnsan Haysiyetinin Korunması Sözleşmesi: İnsan Hakları ve Biyotıp Sözleşmesi” Avrupa Konseyi bünyesinde 4 Nisan 1997 tarihinde imzaya açılmış, TBMM, 3 Aralık 2003 tarih ve 5013 sayılı kanun ile Sözleşme'nin onaylanmasını uygun bulmuştur. Bu kanun uyarınca Sözleşme 16 Mart 2004 tarihinde onaylanmıştır.

Bu çalışmada, Anayasa'nın 90. maddesi uyarınca iç hukukumuzun parçası haline gelmiş söz konusu Sözleşme'ye egemen temel anlayış aktarılmaya gayret edilmiş, bunu yanı sıra Sözleşme'nin temel düzenlemeleri

*Yrd. Doç. Dr., Bilkent Üniversitesi Hukuk Fakültesi Öğretim Üyesi. 
ile Türk ceza mevzuatında yer verilen ilgili hükümler birlikte ele alınarak değerlendirilmiştir.

Kimi hukuksal düzenlemelerin yanı sıra, biyoloji ve tıbbın uygulanmasında biyoetikten kaynaklanan temel ilkelerin önemli bir işlevi bulunduğu açıktır. Biyoetik kavramına farklı anlamlar yüklenebilmektedir. Biyoetik kavramının içeriğini belirleyen ilk kaynak tıp etiğidir. Bu noktada hekimlerin doğru ve uygun davranışlarını belirleyen kurallar karşımıza çıkmaktadır. İkinci kaynak ise, ahlak felsefesidir ${ }^{1}$. İnsanlığın yaşadığı köklü gelişme ve dönüşümler sonucunda bugün tıp etiğgi, biyoetiğin asli öneme sahip, kapsamca geniş bir alt başlığı olarak düşünülmektedir. Bu yönüyle biyoetik, tıp etiği ve sağlık hizmeti etik kurallarının ötesinde, çevre etiği, cinsellik gibi konuları da içerir duruma gelmiştir. Genlerin kullanılıp, bunlara etki edilmesini düzenleyen gen etiği (genethics) de bu kapsamda ele alınmalıdır ${ }^{2}$. Biyoetik, ayrıca, bilimsel araştırma ve deney etiği ile de ilgilidir. Sonuç olarak biyoetik, tıp, sağlık hizmetleri, genetik, biyoloji, araştırma gibi alanlarda ahlak felsefesinin temel kurallarını ifade ederken, tıp etiği ve gen etiği, doğal olarak biyoetiğin alt başlıkları olarak karşımıza çıkmaktadır ${ }^{3}$.

Anayasa'nın 90. maddesi ile Türk hukuk düzeninin parçası olan Sözleşme, biyoloji ve tıbbın uygulanmasına ilişkin temel konulardaki biyoetik ilkeleri ya da bu ilkeleri konu alan ahlak felsefesi tartışmalarını hukuk dünyasına aktarmıştır. Sözleşme ile, aralarında tüpte embriyonlar üzerinde kök hücre çalışmalarının da bulunduğu kimi temel tartışmalar sadece biyoetiğin ya da münferit bazı ulusal hukuk düzenlerinin sorunu olmaktan çıkıp genel bir hukuksal düzenleme konusu olmuştur.

\section{Biyoloji ve Tıbbın Uygulanması Bakımından İnsan Hakları}

Dillerden düşmeyen "küreselleşme" kavramından, biyoloji ve tıbbın uygulanmasına ve bu alandaki ilerlemelere rehberlik eden biyoetik de kendine düşen payı almıştır ${ }^{4}$. Bilim ve araştırmaların hızla küreselleşmesi, biyoetik alanında bazı ortak ilkelerin kabul edilmesini zorunlu kılmaktadır ${ }^{5}$. Bu çerçevede, küreselleşmenin etik alana ilişkin sonuçlarının saptanması da mümkündür. Biyoetiğin küreselleşmesi farklı anlamlara gelmektedir. Bir kere, Batı kültürü dışındaki etik değerlendirmelerin de dikkate alınmaya başlanması bu anlamlardan biri olabilir. Kültürel sınırları aşan biyoetik

${ }^{1}$ HARRIS, John; Bioethics, Oxford Readings in Philosophy, Oxford University Press, 2004, S. 1.

${ }^{2}$ HARRIS, a.g.e.,s. 3.

${ }^{3}$ HARRIS, a.g.e.,s. 4.

${ }^{4}$ HARRIS, a.g.e., s. 5.

${ }^{5}$ ANDORNO, Roberto, "Biomedicine and international human rights law: in search of global consensus", Bulletin of World Health Organization, Vol. 80, No. 12, Geneva, 2002, http://www.scielosp.org/scielo (01.11.2005), par 2. 
konulara işaret edilmesinin yanı sıra biyoetiğin küreselleşmesi deyimi bugün ayrıca, biyoetik alanında ulusal ya da uluslararası etik kurulların, ilgili kuruluşların, sözleşme, protokol, bildirge ya da raporların güç kazanmasını da ifade etmektedir. Bu gelişmenin önemli bir göstergesi, biyoetiğin kurumsallaşmasıdır ${ }^{6}$. Biyoetik alanındaki bu gelişme, ayrıca insan hakları hareketinin, biyotıbbı, insan onuru ile temel hak ve özgürlüklerin korunacağ 1 yeni bir alan olarak kabul etmesinin sonucudur. Bu çerçevede, insan hakları mücadelesinin yeni alanları arasına tıp ve genetik araştırmalar da katılmıştır. $\mathrm{Bu}$ alandaki hızlı gelişmeler yeni, karmaşık etik sorunlar yaratırken, yeni tekniklerin kötüye kullanılması bakımından hukuktan beklentiler $\operatorname{artmaktadır}^{7}$. Biyoetiğin uluslararası düzlemde kurumsallaşmasında dikkati çeken nokta insan onuru kavramına verilen özel önemdir. Birleşmiş Milletler İnsan hakları Evrensel Bildirgesi'nin Başlangıç bölümününün ilk paragrafında "Insanlık ailesinin tüm üyelerinin sahip olduğu onurun, eşit ve devredilemez hakların tanınması, dünyada özgürlü̈̆̈̈n, adaletin ve barışın temeli olduğ u.." kabul edilmiştir. İnsanlık ailesinin tüm üyelerinin sahip olduğu insan onuru, insan hakları ve demokrasinin temelidir ${ }^{8}$. Avrupa Konseyi İnsan Hakları ve Biyotıp Sözleşmesi de biyoetik sorunlarını insan hakları hukuku çerçevesine oturtmuştur'. Sözleşme, bu alandaki ilk bağlayıcı insan hakları belgesidir ${ }^{10}$. İnsan onuru tanımlanması güç bir değer ise de, bu kavram anılmaksızın insan hakları sorunsalına değinilmesi neredeyse olanaksızdır. Kavram, genellikle insanın temel değer oluşu ve kişi dokunulmazlığ 1 ile ilişkilendirilmektedir. Kant'ın deyimiyle insan onuru, insanın araç değil amaç olarak kabul edilmesidir ${ }^{11}$. Tek başına tanımlanması güç bu kavramın biyoetik-biyotıp alanında, aydınlatılmış hastanın rızası, vücut bütünlüğ̈̈, ayrımcılık yasağı, özel yaşamın gizliliği, meslek sırrı gibi somut kavramlar ile birlikte kullanılması söz konusudur ${ }^{12}$. İnsan hakları bu yönüyle, "evrensel etiğin dili", "uluslararası ilişkilerin lingua franca"'sı (ortak dili) olarak kabul edilebilmiştir ${ }^{13}$.

Bu alandaki en önemli uluslararası belgeler 1947 Nürnberg Kuralları, 1948 Birleşmiş Milletler İnsan Hakları Evrensel Bildirgesi, 1964 Helsinki Bildirgesi, UNESCO İnsan Genomu ve İnsan Hakları Evrensel Bildirgesi ve

${ }^{6}$ HARRIS, a.g.e., s. 5.

${ }^{7}$ ANDORNO, a.g.e., par. 5.

${ }^{8}$ ANDORNO, a.g.e., par. 7.

9 SCHOTSMANS, Paul T., "Integration of Bioethical Principles and Requirements into European Union Statues Regulations and Policies", Acta Bioethica. Vol. 11, No. 1, 2005 http://www.scielo.cl/scielo (01.11.2005), par. 8.

10 WINTER, Stephan F., "The Cornerstones for a Prohibition of Cloning Human Beings laid down in the Convention on Human Rights and Biomedicine", European Journal of Health Law, No. 4, 1997, Kluwer Law International, s. 74.

${ }^{11}$ Bkz. ANDORNO, a.g.e., par. 7; HONNEFELDER, Ludger, "Bioethics an Human Genetics: Consensus Formation in Europe", Philosophiches Seminar der Universitat Bonn, Lehr und Forschungsbereich II, par. 16.

${ }^{12}$ ANDORNO, a.g.e., par 8; de WACHTER, Maurice A.M., "The European Convention on Bioethics", Hastings Center Report, January-February 1997, s. 19.

${ }^{13}$ Bkz. ANDORNO, a.g.e., par. 9. 
Oviedo Sözleşmesi olarak da bilinen Avrupa Konseyi İnsan Hakları ve Biyotıp Sözleşmesi'nden oluşmaktadır. Son iki metin, günümüzdeki uluslararası biyotıp hukukunun temel kaynaklarını oluşturmaktadır ${ }^{14} . \mathrm{Bu}$ konudaki UNESCO Bildirgesi, esasen genetik araştırmalara odaklanmakla birlikte hukuken bağlayıcı bir metin değildir. Buna karşılık, Avrupa Konseyi Sözleşmesi, taraf devletleri bağlamakta, bunlara çeşitli yükümlülükler getirmektedir ${ }^{15}$.

Bir Avrupa biyoetik hukukunun oluşturulmasına yönelik Oviedo Sözleşmesi bu alandaki uluslararasılaşmanın önemli metinlerindendir ${ }^{16}$. Avrupa Konseyi üyesi ülkelerin yanı sıra, Sözleşme'nin Konsey üyesi olmayan ülkelerin de katılımına açık olması dolayısıyla kültürel bakımdan çok farklı ülkelerin kendilerini bağlayacağı ortak bir metin oluşturulmaya çalışılmıştır ${ }^{17}$. Ülkelerin tek başlarına bu tür sorunlarla mücadele etmeleri güçtür. Çeşitli ülkelerde, özellikle üremeye yardımcı tekniklere ilişkin hukuksal düzenleme faklarının, katı sınırlamaların kabul edildiği ülkelerden görece serbest ülkelere doğru bir "in vitro tourism"'e ya da "üreme turizmine" ${ }^{\text {18 }}$ yol açtı̆̆ vurgulanmıştır ${ }^{19}$. İşte Sözleşme, bir yönüyle bu tür bir "olumsuz" çeşitliliğge son vermek amacına da yöneliktir ${ }^{20}$.

1982 yılında, Avrupa Konseyi Parlamenterler Meclisi, 934 sayılı Tavsiye Kararı ile, gelecek nesillere uygulanacak genetik teknikleri düzenleyen bir sözleşmenin hazırlanmasını öngörmüştü. Sözleşme, Avrupa Konseyi Genel Sekreteri'nin önerisi üzerine Konsey üyesi devletler adalet bakanları komitesi tarafından 1990 yılında alınan 3 numaralı karar ve Parlamenterler Meclisi'nin biyoetik konusundaki temel ilkeleri içeren ve ek protokollerle tamamlanacak bir sözleşme hazırlanması yönündeki 1160(1991) sayılı tavsiye kararıyla başlayan sürecin sonunda kabul edilmiştir. Konu ad hoc biyoetik komisyonunda ele alınmış, daha sonra bu ad hoc komite sürekli bir komiteye dönüştürülmüss, Parlamenterler Asamblesi, Avrupa Konseyi, Bilim ve Teknoloji, Hukuk ve İnsan Hakları, Toplumsal Sorunlar, Sağlık ve Aile komisyonları ile birlikte çalışarak Sözleşme ile ek protokollere ilişkin konuları ele almıştır ${ }^{21}$. Metin 19 Kasım 1996 tarihinde Bakanlar Komitesi tarafından kabul edilmiştir. Karşı oy bulunmamakla birlikte Belçika, Almanya ve Polonya çekimser oy

${ }^{14}$ ANDORNO, a.g.e., par. 5; SANTANIELLO, Giuseppe, "Ricerca genetica e tutela della persona", http://www.interlex.it/675/santaniello2.htm (09.11.2005), par. 2, 3.

${ }_{15}^{15}$ ANDORNO, a.g.e., par. 5; HONNEFELDER, a.g.e., par. 9.

16 PICIOCCHI, , s. 1. ;de WACHTER, a.g.e., s. 13; PENNINGS, Guido, "Legal Harmonization and Reproductive Tourism in Europe", Human Reproduction. Vol. 19. No. 12, 2004, s. 2693.

${ }^{17}$ PICIOCCHI, Cinzia, "La Convenzione di Oviedo sui diritti dell'uomo e la biomedicina: Verso una bioethica europea?", Diritto pubblico ed europeo, III, 2001, s. 1; SANTANIELLO, a.g.e., par. 3 .

${ }^{18}$ PENNINGS, a.g.e., s. 2690.

${ }^{19}$ PICIOCCHI, a.g.e., s. 8; ANDORNO, a.g.e., par. 2.

${ }^{20}$ PICIOCCHI, a.g.e., s. 8.

${ }^{21}$ PICIOCCHI, a.g.e., s. 3; de WACHTER, a.g.e., s. 13. 
kullanmıştır. 4 Nisan 1997 tarihinde imzaya açılan Sözleşme'ye Konsey üyesi olmayan ülkelerin katılması olanaklı kılınmıştır. Bir ortak biyoetik anlayışının Avrupa sınırları dışına taşınması amacı da söz konusu olmaktadır ${ }^{22}$. Nitekim, Sözleşme'nin hazırlanması sırasında, Konsey üyesi olmayan Kanada, Avustralya, Amerika Birleşik Devletleri gibi ülkelerin yanı sıra, OECD, UNESCO, Dünya Sağlık Örgütü gibi uluslararası örgütler ya da alt kuruluşların temsilcileri de gözlemci olarak hazır bulunmuşlardır ${ }^{23}$.

Sözleşme'nin Başlangıç bölümünde Birleşmiş Milletler İnsan Hakları Evrensel Bildirgesi, Avrupa İnsan Hakları Sözleşmesi, Avrupa Sosyal Şartı, Birleşmiş Milletler Uluslararası Medeni ve Siyasi Haklar Sözleşmesi ve Uluslararası Ekonomik, Sosyal ve Kültürel Haklar Sözleşmesi, Kişisel Verilerin Otomatik İşlenmesine Karşı Bireylerin Korunması Avrupa Sözleşmesi ve Çocuk Hakları Sözleşmesi'nin "gözönünde bulun(durulduğu)" belirtilmekte, Avrupa Konseyi üyeleri arasında daha güçlü bir birliğe insan hakları ve temel özgürlüklerin güçlendirilmesi yoluyla ulaşılacağı inancı dile getirilmektedir. Bunun ardından biyoloji ve tıbbın kötüye kullanılmasının insan onuruna zarar vermesinin önlenmesi, biyoloji ve tıbbın yararlarından, bu alandaki ilerlemeden, gelecek kuşaklar ile tüm insanlığın yararlanabilmesi için uluslararası işbirliğinin önemine dikkat çekilmektedir. Başlangıç kısmında, biyoloji ve tıbbın uygulanmasında insan onuru, bireyin temel hak ve özgürlükleri esas hukuksal çerçeve ve mücadele alanı olarak ortaya konmaktadır.

Avrupa Birliği Temel Haklar Şartı'nda yer alan düzenlemeler bakımından da Sözleşme'nin önemli etkisi olduğu, buradaki bazı hükümlerin, Şart metnine girdiği tespit edilmektedir ${ }^{24}$. Sözleşme'nin birinci maddesinde "Bu Sözleşmenin Tarafları, tüm insanların haysiyetini ve kimliğini koruyacak ve biyoloji ve tıbbın uygulanmasinda ayırım yapmadan herkesin, bütünlüğüne ve diğer hak ve özgürlüklerine saygı gösterilmesini güvence altına alacaklardır" dendikten sonra ikinci fikrada "Tarafların her biri, bu Sözleşme hükümlerinin yürürlüğe sokulması bakımından kendi iç hukuklarında gerekli tedbirleri alacaklardır" hükmüne yer verilmiştir. Sözleşme, bu yönüyle insan onurunu ve insan hak ve özgürlüklerini, biyoloji ve tıbbın uygulanması bakımından merkeze oturtmakta, yukarıda değinildiği gibi, ortak bir biyoetiğin oluşumunda insan hakları çerçevesinde özellikle insan onuruyla bağlantılı bir hat oluşturulmaktadır ${ }^{25}$. Tibbi kötü uygulamalar ya da tıbbın kötüye kullanılması, kültürel farklılıkları aşan, uluslararası

${ }^{22}$ PICIOCCHI, a.g.e., s. 3; de WACHTER, a.g.e., s. 15; SCHOTSMANS, a.g.e., par. 9, 10; MANUEL, C., HAIRON, D., AUQUIER, P., REVIRON, D., GIOCANTI, D., TERRIOU, P., PELLISSIER, V., SAN MARCO J.L., "Is the Legislation of European States in Keeping with the Recent Convention on Human Rights and Biomedicine?", European Journal of Health Law, Vol. 6, 1999, Kluwer Law International, s. 55.

${ }^{23}$ de WACHTER, a.g.e., s. 13.

${ }^{24}$ PICIOCCHI, a.g.e., s. 5, ayrica bkz. Aynı sayfada 15 numaralı dipnot.

${ }^{25}$ de WACHTER, a.g.e., s. 19; SCHOTSMANS, a.g.e., par. 9; SANTANIELLO, a.g.e., par. 15. 
toplumun ortak bir sorunu olarak insan hakları alanında yerini kolaylıkla almış ve oydaşmayı kolaylaştırmıştır ${ }^{26}$. Sözleşme kapsamında temel hak ve özgürlükler ile insan onuru kavramlarının, insan onuru, yaşam hakkı, insan kimliği, vücut bütünlüğü, hasta özerkliği, ayrımcılık yasağı, özel yaşamın gizliliğine saygı, sağlık hizmetlerinden adil biçimde yararlanmadan oluştuğu görülmektedir ${ }^{27}$.

Özellikle sağlık hizmetlerinden yararlanmada sosyal adalet arayışı, Avrupa biyoetiğinin, bireyci ve özerklik kavramını merkeze oturtan Amerikan anlayışından farklı olarak, insan onurunu, toplumsal bir çerçeveye oturtmakta olduğunu göstermektedir ${ }^{28}$. Sadece özerklik ve kendi geleceğini tayin hakkının değil, özel olarak insanın temel varlık ve gelişme koşullarının korunması söz konusudur ${ }^{29}$. Sözleşme'de, biyotıp uygulamalarıyla ilgili koruyucu düzenlemelerin yanı sıra sağlık hizmetlerinden yararlanılması konusunda da temel hükümler yer almaktadır ${ }^{30}$.

$\mathrm{Bu}$ alandaki temel ilkeleri içeren uluslararası metinlerin kaleme alınması, kültürel çeşitlilik dolayısıyla güçtür. Bununla birlikte uluslararası toplumun, iletişim içinde temel ilkelere ulaşması mümkündür ${ }^{31}$. Avrupa Konseyi'nde de böyle bir metnin hazırlanmasında elbette büyük güçlükler yaşanmıştır. Etik, dinsel ve kültürel değerlerin etkili olduğu bu alanda farklı ülkeler arasında uzlaşma sağlanması güç olmuştur. Bu güçlük, kimi zaman çalışma tutanaklarında, kimi zaman ise, Sözleşme metninde yer alan kimi muğlak ifadelerde kendini göstermektedir ${ }^{32}$. Birinci maddede, Türkçe metindeki karşılığı ile "tüm insanlar" ve "herkes" ifadelerinde olduğu gibi farklı sözcüklerin kullanıldığına dikkat çekilmekte, bu sözcüklerin farklı anlamlara sahip olup olmadığının tartışıldı $\breve{g}_{13}^{33}$ dile getirilmektedir ${ }^{34}$. Bu noktada, söz konusu kavramların içeriğinin ulusal mevzuat tarafından berraklaştırılacağı belirtilmekte, Sözleşme'de birçok hüküm ile taraf devlet iç hukukuna gönderme yapıldı ̆̆ına dikkat çekilmektedir ${ }^{35}$. Bunun yanı sıra Sözleşme'de berrak ve kesin tanımı, taraf devlet ulusal mevzuatında bulunmayan kavramlara da yer verilebilmektedir. Bu gibi durumlarda

${ }^{26}$ HONNEFELDER, a.g.e., par. 14.

${ }^{27}$ de WACHTER, a.g.e., s. 19

${ }^{28}$ SCHOTSMANS, a.g.e, par. 30; sosyal hakların önemi bakımından NYS, Herman, "Patients Rights in a European Health Care Market", Paper prepared for delivery at the Conference on European Integration and Health Care Systems: A Challenge for Social Policy, 7-8 December 2001, s. 4, 5; HONNEFELDER, a.g.e., par. 11.

${ }^{29}$ HONNEFELDER, a.g.e., par. 11.

${ }^{30}$ NYS, a.g.e., s. 4,5

${ }_{32}^{31}$ ANDORNO, a.g.e., par. ; karş1 görüş için PENNINGS, a.g.e., s. 2692.

${ }^{32}$ PICIOCCHI, a.g.e., s. 5.

${ }^{33}$ PICIOCCHI, a.g.e., s. 5; de WACHTER, a.g.e, s. 19; farklılıklar konusunda ayrica PENNINGS, a.g.e, s. 2693.

${ }^{34}$ İngilizce metinde, "human beings" ve "everyone", Fransızca metinde "etre humain" ve "toute personne" ifadelerine aynı maddede ayrı ayrı yer verilmiştir.

${ }^{35}$ PICIOCCHI, a.g.e., s. 5; de WACHTER, a.g.e, s. 19. 
kavramın içeriği taraf devletlerin yargılama makamlarına kalmaktadır. Sözleşme'nin 6. maddesinde “..muvafakat verme yeteneği bulunmayan bir kimse üzerinde tıbbi müdahale, sadece onun doğrudan yararı için yapılabilir" ifadesine yer verilmiştir. Buradaki "doğrudan yarar" ifadesinin anlamı ayrıca belirtilmiş değildir. Bu durumda iş yargıya kalmaktadır. 1999 yılında Milano İstinaf Mahkemesi, uzun yıllardır bitkisel hayatta olan bir hastanın kızının, beslenmesinin durdurulması yolundaki başvuruyu, hastanın "doğrudan yararına" olup olmadığının belirlenmesindeki güçlüğe dayanarak reddetmiştir ${ }^{36}$. Kimi kavramların taraf devlet hukuk uygulamalarında tanımlanabilmesi, Sözleşme'de benimsenen kavramların ulusallaşması ve bu nedenle ancak minimal bir etik Avrupa standardının oluşabilmesi tehlikesine dikkat çekilmektedir. Çeşitlilik, taraf devlet hukuku sayısı kadar hukuksal düzenlemeye yol açarsa, Sözleşme'den beklenen yararın sağlanmasında güçlük yaşanacaktır ${ }^{37}$.

Sözleşme, bazı konularda bilinçli olarak susmaktadır. Bu çerçevede, ötanazi konusunda bir düzenleme yapılmamış olmasını boşluk olarak değerlendirmek doğru değildir ${ }^{38}$. Farklı kültürel yapılardaki devletlerin bu konuda uzlașmalarındaki güçlük, hatta olanaksızlık açık bir hükmün sevkedilmesine engel oluşturmuştur ${ }^{39}$. Kimileri ötanazinin insan onuruna aykırı olduğunu düşünürken, kimi yazarlar da insan onurunun ölüm hakkının tanınmasıyla korunabileceği kanısındadır ${ }^{40}$. Ortak ve temel bir metnin kapsamı bakımından kimi zaman muğlak ifadelere yer verilmesi, kimi zaman bilerek bir düzenleme yapılmaması salt farklı devletlerin varlığı ile ilgili bir sorun olmayıp ayrıca her bir taraf devletin kendi içindeki kültürel farklılıkların da önemli etkisi olduğu belirtilmektedir ${ }^{41}$. Fransa'da, tedavi amaçlı (terapötik) klonlama konusunda Etik Ulusal Danışma Komitesi ile İnsan Hakları Ulusal Danışma Komitesi farklı görüş bildirebilmişlerdir. Benzer duruma İngiltere'de de rastlanmıştır ${ }^{42}$.

Sözleşme, ve biyotıpta uyumlaştırma ile ilgili bir başka eleştiri ise, uyumlaştırmanın yönüne ilişkindir. Uyumlaştırma, farklı yaklaşımların bir ve aynı yönde birleşmesi ise, bu yönün temel niteliği özel öneme sahiptir. Uzlaşı ve uyumlaştırma özgürlükler doğrultusunda mı yoksa kısıtlamalar yönünde mi gerçekleşecektir? Bir yazar uyumlaştırma için "kuzu postunda kurt mu?" sorusunu yöneltiyor ${ }^{43}$. Bu çerçevede, Sözleşme'nin, esasen biyotıp alanında bir kısıtlamalar metni oluşturduğu eleştirisinin de gözardı edilmemesinde yarar vardır.

\footnotetext{
${ }^{36}$ PICIOCCHI, a.g.e, s. 6,7.

${ }^{37}$ PICIOCCHI, a.g.e, s. 9.

${ }^{38}$ PICIOCCHI, a.g.e, s. 7.

${ }^{39}$ PICIOCCHI, a.g.e, s. 7.

${ }^{40}$ PENNINGS, a.g.e., s. 2692.

${ }^{41}$ PICIOCCHI, a.g.e, s. 7

${ }^{42}$ PICIOCCHI, a.g.e, s. 7, 8 .

${ }^{43}$ PENNINGS, a.g.e., s. 2692.
} 
Tüm bu sıkıntılara karşın, Sözleşme'nin bir Avrupa biyoetik çevresinin oluşumunda önemli katkılar sağlayacağı savunulmaktadır. Özellikle aydınlatılmış hastanın rızasını merkeze oturtan Sözleşme ile "pederşahiotoriter" hekim hasta ilişkisinin, rızaya dayalı bir "tedavi sözleşmesine, tedavi ilişkisine" dönüşmesi yüksek sesle tekrar ilan edilmektedir ${ }^{44}$. Hasta, artık bağımsız bir ahlak öznesidir ${ }^{45}$.

Sözleşme'nin diğer bir olumlu katkısının ise, bireyin hukuken korunmasında söz konusu olacağı dile getirilmektedir. Yasakoyucu, yeni bilimsel gelişmelerin hızına ayak uyduramamakta, bu nedenle kişiliğin korunmasında zaaflar doğabilmektedir. Bu çerçevede, özellikle bazı hastalıkların nedeni olarak tespit edilen genlere ilişkin kişisel verilerin korunması konusunda Sözleşme yükümlülük getirmektedir. Kişilerin yakalanması olasılığı bulunan hastalıkların nedeni olan genleri taşıdığının belirlenmesi, tedavi bakımından yararlı olduğu kadar, bu verilerin korunmaması, toplumsal yaşamda, iş yaşamında, sigorta alanında ayırımcılığa neden olması son derece tehlikelidir. Bu noktada Sözleşme'nin bu tür bir ayrımcılığa engel oluşturacak temel bir metin olduğu söylenmelidir ${ }^{46}$.

Bunun gibi başkaca hükümleri de olan Sözleşme'de yer verilen kavramların doğru ve gerçek anlamlarının tespiti, yani yorumu bakımından disiplinlerararası çalışma şarttır. Bunun yanı sıra Sözleşme'nin 28. maddesinde belirtildiği üzere biyoloji ve tıp alanındaki gelişmelerin, uygun biçimde kamuya açık değerlendirilmeleri gerekmektedir ${ }^{47}$. Maddede, " $B u$ Sözleşmenin Tarafları, biyoloji ve tıp alanındaki gelişmelerin doğurduğu temel sorunların, özellikle ilgili tıbbi, sosyal, ekonomik, ahlaki ve hukuki yansımaların ışı̆̆ında, uygun şekilde kamusal tartışmaya konu olmasını ve bunların muhtemel uygulamalarının, uygun istişarelere konu olmasinı sağlayacaktır" hükmüne yer verilmiştir.

Bir Avrupa biyoetiğinin kurulması önemli olmakla birlikte böyle bir biyoetik çevresinin oluşturulması, farklı ülke kültürlerinin yok sayılacağı anlamına gelmemekte, kültürel farklara saygı çerçevesinde ortaklaştırma yoluna gidilmesi gerektiği dile getirilmektedir. Bununla birlikte, bir ortak hukukun oluşturulabilmesi bakımından dikkate alınması gereken, genel ve geniş anlamda farklar değil, yaşamın başlangıcı ve sonu gibi, belirli özel konulardaki farklı değerlerdir ${ }^{48}$.

Öte yandan, bir uluslararası metnin hazırlık sürecine çok farklı kültürlerin katılması, sonuca ulaşılmasını zorlaştırmakla birlikte, İnsan

\footnotetext{
${ }^{44}$ PICIOCCHI, a.g.e., s. 10; SCHOTSMANS, a.g.e., par 14; HONNEFELDER, a.g.e., par 12.

${ }^{45}$ SCHOTSMANS, a.g.e., par 14.

${ }^{46}$ PICIOCCHI, a.g.e., s. 11

${ }^{47}$ PICIOCCHI, a.g.e., s. 12

${ }^{48}$ PICIOCCHI, a.g.e., s. 13
} 
Hakları Evrensel Bildirgesi’nde olduğu gibi geniş bir katılımla oluşturulan uluslararası metinler daha etkili görünmektedir ${ }^{49}$. Uluslararası biyotıp metinlerinde hükümler temenni niteliğinde değildir. Ulusal hukuk düzenlerine etki ederek bu ülke düzenlemelerinin dönüşümünü de sağlamaktadır ${ }^{50}$.

\section{Sözleşme'nin Bağlayıcılı̆̆ı}

Sözleşme'nin, taraf devletler bakımından bağlayıcılığının derecesi konusunda çeşitli görüşler dile getirilmektedir. Yirmiüç ve 25. maddelerde, taraf devletlerin Sözleşme'de öngörülen hak ve ilkelerin hukuka aykırı biçimde ihlal edilmesini önlemek amaciyla uygun yargısal korumayı sağlamaları ve Sözleşme hükümlerine uyulmasını teminat altına almak üzere, hukuk düzenlerinde uygun yaptırımlar öngörmeleri gerektiği hükme bağlanmaktadır. Öte yandan 30. madde gereği, Avrupa Konseyi Genel Sekreteri'nin talebi üzerine, taraf devletler, Sözleşme hükümlerinin etkin biçimde uygulanması bakımından benimsedikleri hukuksal aygıtlara ilişkin gerekli bilgileri verecektir ${ }^{51}$. Bunun yanı sıra, Avrupa İnsan Hakları Mahkemesi, 29. madde uyarınca Sözleşme'nin yorumu konusunda çıkan hukuksal sorunlar bakımından istişari görüş bildirebilecektir. Bu görüş, sürmekte olan bir davayı doğrudan etkilemek amacına yönelik değildir ${ }^{52}$.

Sözleşme'nin 26. maddesinde, “Sözleşme'de yer alan haklar ve koruyиси hükümlerin kullanılmasında, kamu güvenliği, suçun önlenmesi, kamu să̆lığının korunması veya başkalarının hak ve özgürlüklerinin korunmast için kanun tarafından öngörülen ve demokratik bir toplumda gerekli olanlardan başka kısıtlama konulmayacaktır" demek suretiyle anılan nedenlerle haklardan yararlanılması konusunda sinırlamalar getirilmesini yolu açılmıştır. Bununla birlikte aynı maddenin ikinci fıkrası bu tür sınırlamaların yine Sözleşme'nin genetik kalıtım dolayısıyla ayrımcılı̆̆ 1 yasaklayan 11, önleme, teşhis ve tedavi dışında insan genomuna müdahaleyi yasaklayan 13, cinsiyet seçimi amacıyla suni döllenme tekniklerini kullanılmasını yasaklayan 14, üzerinde araştırma yapılan kişilerin korunmasını öngören 16, araştırmaya rıza yeteneği olmayan kişileri koruyan 17, canlı donörden organ nakline ilişkin genel kuralı koyan 19, rıza yeteneğine sahip olmayan donörün korunmasına yönelik 20 ve insan vücudunun ve parçalarının, bu nitelikleri ile ticari kazanca konu olmasını yasaklayan 21. maddeleri bakımından mümkün olmadığını kesin bir ifade ile hükme bağlamaktadır. Sınırlanması mümkün olmayan hak ve koruyucu hükümlere ilişkin bu düzenlemeler, Sözleşme'nin özünü oluşturmaktadır ${ }^{53}$.

\footnotetext{
${ }^{49}$ ANDORNO, a.g.e., par. 10.

${ }^{50}$ ANDORNO, a.g.e., par. 13.

${ }^{51}$ PICIOCCHI, a.g.e., s. 1, 3.

${ }^{52}$ PICIOCCHI, a.g.e., s. 2.

${ }^{53}$ PICIOCCHI, a.g.e., s. 4; de WACHTER, a.g.e., s. 14.
} 
Metnin 27. maddesi gereği, taraf devletlerin, Sözleşme ile öngörülenden daha geniş bir hukuksal koruma sağlamalarına engel yoktur. Maddeye göre, "Bu Sözleşmedeki hükümlerden hiçbiri, Tarafların, biyoloji ve tıbbın uygulanmasında bu Sözleşmede belirtilenden daha geniş bir koruma sağlama imkânını kisıtlayacak veya etkileyecek şekilde yorumlanmayacaktır". Sırf Sözleşme ile getirilen korumanın kapsamına uyum sağlamak adına iç hukuktaki mevcut ve görece geniş hukuksal korumanın daraltılması Sözleşme'nin amaçlarıyla bağdaşmayacaktır ${ }^{54}$.

$\mathrm{Bu}$ çerçevede, aralarında Türkiye Cumhuriyeti'nin de bulunduğu taraf devletlerin, kanun çıkarmak suretiyle dahi Sözleşme'nin özü niteliğindeki bu haklar ve düzenlemeleri sınırlandırması mümkün değildir. Öte yandan, Türkiye'de yasakoyucunun böyle bir kanunu çıkarması durumunda dahi bu sefer Anayasa'nın 90. maddesinin son fıkrası gereği uygulayıcının, Sözleşme hükümlerine üstünlük tanıması zorunludur. 2004 yılında Anayasa'nın 90. maddesinin son fıkrasına eklenen "Usulüne göre yürürlüğe konulmuş temel hak ve özgürlüklere ilişkin milletlerarası andlaşmalarla kanunların aynı konuda farklı hükümler içermesi nedeniyle çıkabilecek uyuşmazlıklarda milletlerarası andlaşma hükümleri esas alını" cümlesi ile bir insan hakları sözleşmesi olan Avrupa İnsan Hakları ve Biyotıp Sözleşmesi'nin önceliği de teminat altına alınmış olmaktadır.

Sözleşme'de doğrudan uygulama kabiliyeti bulunan birçok hüküm vardır. İnsanın önceliği ilkesini düzenleyen 2. madde, meslek kurallarına uygun tıbbi müdahaleyi öngören 4. madde Sözleşme'nin genel hükümleri arasında taraf devletlere yasama yükümlülüğü getirmekten çok belirli bir alana ilişkin doğrudan etkili düzenlemeler içermektedir. Gerçekten insanın önceliği ilkesinin düzenlendiği 2 . madde ile insanın menfaatlerinin ve refahının, bilimin ve toplumun menfaatlerinin üstünde tutulacağı hükme bağlanmaktadır. Bir işlevi de esasen menfaatlerin, normlar hiyerarşisi içinde dengelenmesi olan hukuk uygulamasının, hukuksal sorunları çözerken bu ilkeyi dikkate almaması mümkün değildir.

Yine tıbbi müdahalelere rıza ve rızanın usulü, rıza yeteneği bulunmayanlar bakımından uygulanacak kurallar ayrıntılıdır ve doğrudan uygulanma kabiliyetine sahiptir. Sözleşme'nin "Muvafakat" başlığ 1 altında düzenlenen ikinci bölümünde konuyla ilgili beş maddeye yer verilmiş, özellikle rıza yeteneği bulunmayanlara ilişkin hükümlerden 6 . maddede konu ayrıca beş bağımsız paragrafta ayrıntılı biçimde düzenlenmiştir ${ }^{55}$.

${ }^{54}$ MANUEL, C., HAIRON, D., AUQUIER, P., REVIRON, D., GIOCANTI, D., TERRIOU, P., PELLISSIER, V., SAN MARCO J.L., a.g.e., s. 63.

55 "Madde 6. (Muvafakat verme yeteneği bulunmayan kişilerin korunması)

1. Aşağıda, 17 ve 20. maddelere tabi olmak koşuluyla, muvafakat verme yeteneği bulunmayan bir kimse üzerinde tıbbi müdahale, sadece onun doğrudan yararı için yapılabilir.

2. Kanuna göre bir müdahaleye muvafakatini verme yeteneği bulunmayan bir küçüğe, sadece temsilcisinin veya kanun tarafından belirlenen makam, kişi ya da kuruluşun izni ile 
Özel yaşam ve bilgilendirilme hakkını düzenleyen 10. maddede de taraf devlete yönelik bir program hüküm söz konusu olmayıp, kişinin kendi sağlığı ile ilgili bilgileri öğrenme hakkından vazgeçmesine varıncaya kadar konu ayrıntılı biçimde düzenlenmiştir. İnsan genomu üzerinde araştırmaları düzenleyen 11 ila 14. maddeler bakımından da benzer şeyler söylenebilir. Onbirinci maddede "Bir kimseye, genetik kalıtımı nedeniyle herhangi bir ayrımcılık uygulanması yasaktır" denmekle ayrıca taraf devletlere böyle bir yasağın gelecekte yasal olarak öngörülmesi yönünde bir yükümlülük getirilmemekte, konu doğrudan düzenlenmektedir. Onüçüncü maddede, insan genomu ile ilgili çalışmaların sadece teşhis ve tedavi amacıyla yapılabileceği, 14. maddede ise, doğacak çocuğun cinsiyetini seçmek amacıyla suni döllenme tekniklerinden kaçınılacağı açıkça hükme bağlanmaktadır. Bilimsel araştırmaya ilişkin 15 ila 20. maddeler bakımından da durum böyledir. Araştırmalar bakımından rıza yeteneği bulunmayanların durumunu düzenleyen 17. maddeye aykırı bir çalışmanın Türkiye'de de yürütülememesi gerekir. Bu kapsamda, rıza yeteneği bulunmayanlar üzerinde araştırma yapılabilmesi için "araştırmanın sonuçlarının ilgilinin să̆llğg ïzerinde gerçek ve doğrudan yarar să̆lama beklentisinin bulunması" gerekir (m. 17/par. 1, ii). Yine bu bölümde yer verilen ve tüpte embriyonlar üzerinde araştırmayı düzenleyen 18. maddenin 2. paragrafındaki "Sadece araştırma amaçlarıly insan embriyonlarının yaratılması yasaktır" hükmü dolayısıyla Türkiye'de tedavi amaçlı embriyonik kök hücre çalışmalarının da yasaklandığı sonucuna varmak güç olmayacaktır. Nitekim Sağlık Bakanlığı, 2005 yılı Eylül ayı içinde bir genelge yayınlamak suretiyle bu tür bilimsel çalışmaları yasaklamıştır. Bu örnekleri çoğaltmak için Sözleşme metnine göz atmak yeterlidir.

Nihayet, Sözleşme'nin 25. maddesinde, “Taraflar, bu Sözleşme'de yer alan hükümlerin ihlal edilmesi halinde uygulanacak uygun yaptırımlart sağlayacaklardır" ifadesine yer verilmekle, kural ya da hüküm kısmının Sözleşme'de, yaptırımın ise kanunlarda bulunacağı bir eksik norm oluşturulması yoluna gidilmektedir.

müdahalede bulunulabilir.

Küçüğün görüşü, yaşı ve olgunluk derecesiyle orantılı bir şekilde, gittikçe daha belirleyici bir etken olarak gözönüne alınacaktır.

3. Kanuna göre, akıl hastalığı, bir hastalık veya benzer nedenlerden dolayı, müdahaleye muvafakat etme yeteneği bulunmayan bir yetişkine, ancak temsilcisinin veya kanun tarafından belirlenen kiși veya makamın izni ile müdahalede bulunulabilir.

İlgili kiși mümkün olduğu ölçüde izin verme sürecine katılacaktır.

4. Yukarıda 2 ve 3 . paragraflarda belirtilen temsilci, makam, kişi veya kuruluşa, aynı şartlarda, Madde 5'te belirtilen bilgi verilecektir.

5. Yukarıda 2 ve 3. paragraflarda belirtilen izin, ilgili kişinin en fazla yararı bakımından her zaman geri çekilebilir."

4. paragrafta gönderme yapılan beşinci madde, tıbbi müdahaleye rızanın alınması sırasında bilgilendirme ya da aydınlatma ödevini düzenlemektedir. Görüldüğü gibi, taraf devletlere belli konularda yasal düzenleme yapma yükümlülüğ̈̈ getirmekten çok, belli konularda doğrudan düzenleme öngörülmesi yolu tercih edilmiştir. 
Muhtemelen taraf devletlerin mevcut düzenlemelerinde yer alan yaptırımlar ile bu hükümlerin teminat altına alınması mümkün olabilecektir. Hukukumuz bakımından Sözleşme ile korunan varlık ve menfaatlere ilişkin ceza hükümleri bulunduğu rahatça söylenebilir. Yeri geldiğince bunlara değinilecektir. Bununla birlikte, hukukumuzda açıkça ve özel olarak Sözleşme'nin bazı hükümlerine ilişkin yaptırım belirlenmemiş olsa bile, bu sefer ilgili tıbbi müdahalenin ya da çalışmanın yürütülmesi bakımından emredici özelliğe sahip bu hükümlerin ihlalinin genel hükümlerden hareketle karşılanması, örneğin tazminat sorumluluğuna yol açması mümkündür. Dolayısıyla, Sözleşme hükümlerinin, bağımsız hukuk dallarının özel olarak öngörülecek yaptırımları ile teminat altına alınması kadar, yeri geldiğinde genel hükümlere göre de koruma sağlanması mümkündür. Nitekim 23. maddede "Taraflar, bu Sözleşme'de öngörülen hakların ve ilkelerin hukuka aykır bir şekilde ihlalinin en kısa sürede önlenmesi veya durdurulmast için uygun yargısal korumayı sağlayacaklardır" denmekle, Sözleşme hükümlerinin emredicilik ve doğrudan uygulanırlık özellikleri ilan edilmektedir.

\section{Sözleşme'nin Ana Hatları}

Sözleşme'de ondört bölüm bulunmaktadır. Bu başlıklar arasında ilk bakışta dikkat çeken temel konular, rıza (muvafakat), özel yaşam ve bilgilendirilme hakkı, bilimsel araştırma, tüpte embriyonlar üzerinde araştırma, insan genomu, nakil amaciyla canlı vericiden organ ve doku alınması, ticari kazanç yasağı ve insan vücudundan alınmış parçalar üzerinde tasarruftur.

Sözleşme'de Başlangıç kısmının ardından bir ve dördüncü maddeler arasında "Genel Hükümler" başlığı altında temel bazı ilkelere yer verilmiş, ardından biyotıp alanına ilişkin önemli özel düzenlemelere yer verilmiştir.

\section{Genel Hükümler}

Sözleşme'nin "Genel Hükümler" başlıklı birinci bölümünde "Amaç ve konu", "İnsanın önceliğı", "Sağllk hizmetlerinden adil şekilde yararlanma", "Mesleki standartlar" başlıkları altında dört ayrı maddeye yer verilmiştir.

Sözleşme'nin amacını ve konusunu düzenleyen birinci maddesinin, biyotıbbın insan onuru ve insan hakları çerçevesine yerleştirildiğinin önemli bir göstergesi olduğuna yukarıda değinilmişti. Bu Sözleşme'nin temel amacı, insan onuru ile insan kimliğinin korunması ve ayrım gözetmeksizin herkesin vücut bütünlüğü ile diğer temel hak ve özgürlüklerinin güvence altına alınmasıdır. Biyotıp uygulamaları ve araştırmaları bu temel ilkelere uygun yürütülmek zorundadır ${ }^{56}$.

\footnotetext{
${ }^{56}$ de WACHTER, a.g.e., s. 20.
} 


\section{a. İnsanın Önceliği İlkesi}

Sözleşme'nin ilk bölümünü oluşturan genel hükümler arasında yer alan ikinci madde "insanın önceliğ ĭ" ilkesine yer vermiştir. Maddeye göre "Insanın menfaatleri ve refahı, bilim veya toplumun menfaatlerinin üstünde tutulacaktı".

Maddenin düzenleniş amacı, araştırmaların belli kurallar dairesinde ve insan onuru ile temel hak ve özgürlüklerin sınırları içerisinde yürütülmesidir ${ }^{57}$. Nitekim, Sözleşme'nin bilimsel araştırmalara iliş̧kin genel kuralı düzenleyen 15. maddesinde "Biyoloji ve tıp alanında bilimsel araştırma, bu Sözleşme hükümlerine göre ve insan varlığının korunmasını güvence altına alan diğer yasal hükümlere bă̆lı kalmak kaydiyla, serbestçe yapılabilir" hükmüne yer verilmiştir. Buradan anlaşılması gereken bilimsel araştırma özgürlüğünün tanındığ 1 , ancak bu özgürlüğün mutlak olmadı̆̆ıdır. Biyotıp alanındaki araştırmalar, Sözleşme'de kişi özgürlükleri ve temel haklar bakımından getirilen güvencelere, ve 16. maddenin üçüncü fıkrasında olduğu üzere etik komitelere başvurulması gibi çeşitli yükümlülüklere aykırı olmamak kaydıyla serbestçe yürütülebilecektir ${ }^{58}$.

\section{b. Sağlık Hizmetlerinden Adil Şekilde Yararlanma}

Üçüncü maddede, "Taraflar, să̆lı̆̆a duyulan ihtiyaçları ve kullanılabilir kaynakları gözönüne alarak, kendi egemenlik alanlarında, uygun nitelikteki sağglı hizmetlerinden adil bir şekilde yararlanılmasını sağlayacak uygun önlemleri alacaklardır" hükmüne yer verilmiştir. Taraf devletler bakımından getirilen bu yükümlülük Sözleşme'nin toplumsal bir çerçevede sağlık hizmeti ve hasta haklarını ele aldığını göstermektedir ${ }^{59}$. Hasta hakları bakımından bu noktada da bir ortaklık oluşturulması amaçlardan biridir ${ }^{60}$.

Madde hükmü, sağlık sisteminde dayanışmayı esas alan Avrupa biyoetik geleneğinin bir ürünü olarak değerlendirilebilir. Temel hedef sosyal adaletin gereçekleştirilmesi ise, sağlık hizmetlerinin sosyalleştirilmesi son derece önemlidir. Refah devletinin, salt liberal sözleşmeci medeni hukuk evrenini dönüş̧ürdüğü açıktır ${ }^{61}$. Medeni hukukunun kamusal müdahalelere açılması, devletin, sosyal devlete dönüşmesi dolayısıyla ortaya çıkan ödevleri biyoetik anlayışı bakımından Avrupa çevresine bazı öznitelikler kazandırmıştır. Evrensellik, özgürlük, kardeşlik, modern devletin temel

\footnotetext{
${ }^{57}$ de WACHTER, a.g.e., s. 19.

58 de WACHTER, a.g.e., s. 19, 20; SKENE, Loane, "Patient's Rights or Family Responsabilities? Two Approaches to Genetic Testing", Medical Law Review, No. 6, Spring 1998, Oxford University Press, s. 23.

${ }^{59}$ NYS, a.g.e., s. 4.

${ }^{60}$ NYS, a.g.e., s. 4.

${ }^{61}$ SCHOTSMANS, a.g.e., par. 15.
} 
özellikleri arasında önemli yer tutarak hukuksal yapıların dönüşümünü sonuçlamıştır. Liberal amentü olarak bireysel özgürlük ve bireysel sorumluluk kurgusu, yerini büyük ölçüde devletin, kişinin kendini gerçekleştirmesine ilişkin ödevlerine bırakmıştır ${ }^{62}$.

Kimi iktisadi dönüşümler ve geri gidişlerin varlığına karşın Avrupa sağlık sisteminin temelinde halen bu anlayışın olduğu düşünülmektedir. İşsizlerin sağlık hakları, dayanışmacı anlayışın bir sonucudur. Bir yazarın ifadesiyle sağlık alanında bir insani ya da insancıl dayanışma (humanitarian solidarity) söz konusudur ${ }^{63}$. Bu yaklaşım, piyasa merkezli Amerikan să̆lık anlayışından tamamen farklıdır. Bu sonuncu anlayışın, özerkliği temel etik değer olarak kabul etmesi, Amerikan tıp etiğinin esasen tıbben doğru kararın verilmesi sorunu ile sınırlı olması karşısında Avrupa biyoetik geleneğinden kaynaklanan ileri bir toplumsal içeriğe sahip olduğu tespit edilmelidir ${ }^{64}$. Sözleşme ve Avrupa Konseyi'nin bu konudaki çizgisinin Avrupa Birliği'nin dahi ötesinde olduğu savunulmaktadır ${ }^{65}$. O halde biyoetik alana Avrupa geleneğinin katkısı, biyoetiği, salt bir karar alma yöntemi olarak algılayan sistemlerin ötesine taşıması, yaymasıdır. Bu yönüyle, kaynağını Roma Germen evreninde ve Hipokrat yemininde bulan bu gelenek, dayanışmacı biçimde evrilerek kendi tıp kültürünü sunmaktadır ${ }^{66}$. Tıp hizmetlerinin sosyalleştirilmesi tartışmalarının Altmışlı yıllardan bu yana gündemde olduğu Türkiye Cumhuriyeti'nin, anayasasında yer alan devletin ödevlerine ilişkin hükümler de hatırlandığında, bu geleneğe yabanc1 olmadığı düşünülmeli, piyasa merkezli önerilerin, kamusal bakış açısına alternatif oluşturamayacağı unutulmamalıdır.

Sözleşme'nin 28. maddesinde kamuya açık tartışmanın önemine dikkat çekilmekte, Tarafların, biyoloji ve tıp alanındaki gelişmelerin doğurduğu temel sorunları, özellikle tıbbi, ahlaki, sosyal, ekonomik ve hukuksal sonuçlarıyla kamusal zeminde tartışmaya açmaları beklenmektedir.

\section{c. Meslek Kurallarına Saygı}

Biyoloji ve tıbbın uygulanmasında meslek kurallarına uyulmasını öngören 4. maddede, "Araştırma dahil, sağllk alanında herhangi bir müdahalenin, ilgili mesleki yükümlülükler ve standartlara uygun olarak yapılması gerekir" hükmüne yer verilmiştir. Sözleşme, yazılı olan ya da yazılı olmayan meslek kurallarına uygun müdahaleyi güvence altına almaktadır. Bununla birlikte, biyotıp ve tıp alanındaki müdahalelerin sadece lege artis'e uygun olması yeterli kabul edilemeyecektir. Ayrıca tıbbi

${ }^{62}$ SCHOTSMANS, a.g.e., par. 15.

${ }^{63}$ Bkz. SCHOTSMANS, a.g.e., par. 16.

${ }^{64}$ SCHOTSMANS, a.g.e., par. 17, 23, 24.

${ }^{65}$ NYS, a.g.e., s. 4.

${ }^{66}$ SCHOTSMANS, a.g.e., par. 23, 24. 
uygulamanın tedavi ya da yaşam kalitesinin yükseltilmesi amacına yönelmesi zorunludur. Sözleşme'nin 7, 8, 18, 19 ve 20. maddelerinde sağlık ya da tedavi amacindan bahsedilmek suretiyle bu temel ilke de güvence altına alınmaktadır ${ }^{67}$. Tedavi amacı bulunması, bilindiği gibi tıbbi müdahalelerin hukuka uygunluk nedenlerinden hakkın icrası ya da yetkinin icrası kapsamında değerlendirilebilmesi için zorunludur. Tedavi amacı, sübjektif sınırı ifade eder ${ }^{68}$.

\section{Sözleşme'de Yer Verilen Kimi Temel Düzenlemeler}

Sözleşme'nin ilk bölümünde yer verilen genel ilkelerin ardından iki ve sekizinci bölümler arasında temel bazı düzenlemelere yer verildiği görülmektedir. $\mathrm{Bu}$ düzenlemeler, esasen doğrudan uygulanma özelliğine sahiptir ve hukukumuz bakımından da özel öneme sahiptir.

\section{a. Sağlık Alanındaki Müdahalelere Rıza}

İkinci bölümde yer verilen ilk temel düzenleme sağlık alanındaki müdahalelere rıza konusundadır. Sözleşme'nin 5 ila 9, 10 ve 22. maddeleri aydınlatılmış hastanın rızasına yaşamsal önem verilen hükümlerdir ${ }^{69}$. Beşinci maddede, bu konudaki genel kural sevkedilmiştir. Altıncı maddede rıza yeteneğine sahip olmayanların durumu düzenlenmiş, 7. maddede ise, akıl hastalığg olanların korunması hükme bağlanmıştır. Dokuzuncu maddede ise, müdahale sırasında rıza gösterilmesinin mümkün bulunmadığı durumlarda, önceden verilen rızanın dikkate alınmasına ilişkin düzenleme mevcuttur. Sözleşme'nin 9. maddesinin son fıkrasında "Müdahale sırasında isteğini açıklayabilecek bir durumda bulunmayan bir hastanın, tıbbi müdahale ile ilgili olarak önceden açıklamış olduğu istekler gözönüne alınacaktır" denmektedir. $\mathrm{Bu}$ düzenlemenin Avrupa ortak biyoetiğinin oluşumu bakımından önemli olduğu dile getirilmiş ${ }^{70}$, bu hükümle ifade olunarak güvence altına alınan özerklik ilkesinin Sözleşme'nin temeli olduğu savunulmuştur ${ }^{71}$. Onuncu maddede bilgilendirilme hakkı güvence altına alınmış, 22. maddede ise, insan vücudundan parça alınması bakımından aydınlatılmış hastanın rızası koşulunun yerine getirilmesi aranmıştır. Bilindiği gibi, Türk hukukunda Tababet ve Şuabatı Sanatlarının Tarzı İcrası Hakkında Kanun'un 70. maddesinde, hastanın rızasının alınmaması suç olarak tanımlanmıştır.

${ }^{67}$ HONNEFELDER, a.g.e., par. 13.

${ }^{68}$ BAYRAKTAR, Köksal, Tedavi Nedeniyle Hekimin Cezai Sorumluluğu, İstanbul, 1972, s. 149.

${ }^{69}$ de WACHTER, a.g.e., s. 20.

${ }^{70}$ PICIOCCHI, a.g.e., s. 10

${ }^{71}$ de WACHTER, a.g.e., s. 20. 
Özerklik ilkesinin, bağlayıcı bir uluslararası belgede ilk defa yer alması, hukukçular arasında heyecan yaratmış, olumlu eleştiriler almıştır. Bununla birlikte özerkliğin mutlak biçimde kabulü halinde, bu sefer 2. maddede herşeyden üstün tutulan insanın menfaatlerinin gerçekten gözetilmesinde sıkıntılar yaşanabilecektir. Özerklik, kişinin iradesine öncelik verirken, bu irade, tıbben doğru ve insan menfaatine yargılar ile örtüşmeyebilecektir. Bu durumda 5. maddenin ve diğer ilgili hükümlerin uygulanması, bu sefer gerçekten insanın menfaatlerinin gözetilmemesi sonucunu doğurabilecektir ${ }^{72}$.

Özerklik ilkesini Sözleşme'nin temel değeri olarak kabul eden görüşlere yöneltilebilecek bir başka eleştiri ise, Avrupa biyoetik geleneğinin Amerikan biyoetik anlayışından farklı bir kişilik kavrayışı olduğu yönündedir. $\mathrm{Bu}$ çerçevede, Avrupa geleneği, minimalist bir kişi anlayışına dayalı özerkliğin ötesinde insan onuru, vücut bütünlüğü gibi unsurları da kapsar biçimde kişiliği kurgulamıştır ${ }^{73}$. Salt özerklik ile yetinerek yaşamın kaynağının korunması olası değildir. İnsan onurunun, salt özerklik üzerinden hüküm ifade etmesi olanaksızdır. Embriyona ilişkin insan onuru dolayımlı koruyucu hükümlerin, salt özerklik ile açıklanması güçtür. Avrupa temel etik değerleri, insan özniteliklerinin (karakteristiklerinin) korunması amacına yöneliktir. İnsan kişiliğinin gelişimi temel bir noktadadır. Embriyonun korunmasının yanı sıra, rıza yeteneğinin bulunmadığ 1 yani hasta özerkliğinden bahsedilemeyecek durumlarda ya da kadavranın korunmasında özerklik merkezli minimalist yaklaşımların sonuç veremeyeceği açıktır ${ }^{74}$.

Beşinci maddenin ikinci fıkrasında “..kişiye, önceden, müdahalenin amacı ve niteliği ile sonuçları ve tehlikeleri hakkında uygun bilgiler.." verileceği hükme bağlanmaktadır. İlk Sözleşme taslağında bulunmayan bu fıkra daha sonra metne dahil edilmiş̧ir. Fıkrada yer alan "uygun" ifadesi önemlidir. Bu düzenleme ile amaçlanan, bilgilendirmenin kapsamının somut olayın koşullarına uygun olmasıdır. Buna göre, bilgilendirme tüketici olmak zorunda değildir. Hastanın tedaviden kaçmasını sonuçlayacak derecede korku yaratacak bilgilendirmenin sakıncaları bertaraf edilmek istenmiştir. $\mathrm{Bu}$ noktada, somut durum bakımından gerekli ve yeterli derecede, esasen önemli noktalara, alternatif yöntemlerin mevcudiyetine ve müdahalenin başarısız olmasına ilişkin olası tehlikelere dair bilgilendirme yeterli görülebilecektir ${ }^{75}$. Bununla birlikte bilgilendirme, mutlaka ilgili tarafından anlaşılabilir biçimde yapılmalıdır ${ }^{76}$. Sözleşme'de kabul edilen bu ilkeler de bugün artık Türk hukukunun parçasıdır. Bununla birlikte Sözleşme'ye taraf olunmadan önce de Türk öğretisi ve mevzuatı konuyla ilgili tartışmalara hiç de yabancı

\footnotetext{
${ }^{72}$ de WACHTER, a.g.e., s. 20.

${ }^{73}$ SCHOTSMANS, a.g.e., par. 12 .

${ }^{74}$ SCHOTSMANS, a.g.e., par. 12, 13, 19, 20.

${ }^{75}$ de WACHTER, a.g.e., s. 20.

${ }^{76}$ de WACHTER, a.g.e., s. 20; ayrica MANUEL, C., HAIRON, D., AUQUIER, P., REVIRON, D., GIOCANTI, D., TERRIOU, P., PELLISSIER, V., SAN MARCO J.L., a.g.e., s. 60,61
} 
kalmamıştır. Bugün, Türk hukuk düzeninde, Sözleşme hükümleri dışında da bilgilendirme ya da aydınlatma yükümlülügüünün kapsamına ilişkin düzenlemeler bulunmaktadır. Bu düzenlemeler arasında organ ve doku alınması ve nakline ilişkin Kanun, Tıbbi Deontoloji Nizamnamesi, Hasta Hakları Yönetmeliği ilk akla gelenlerdir. Bu metinlerde ayrıntılı bilgi verilmesine ilişkin düzenlemeler bulunmakla, Yargıtay'ın kimi kararlarında da ayrıntılı bilgi verilmesi aranmakla birlikte, bilgilendirme ya da aydınlatma yükümlülügüünün, hastanın maneviyatını ve tedaviyi olumsuz etkilemesi olasılığı bulunan hallerde bilgilendirmenin sınırlanmasına ilişkin düzenleme de mevcuttur. Bu yöndeki düzenlemeye Hasta Hakları Yönetmeliği'nin 19. maddesinde yer verilmiştiir7 .

Sözleşme'nin aynı maddesinin üçüncü fıkrasında ise, rızanın geri alınması düzenlenmektedir. Fıkrada, "İlgili kişi, muvafakatini her zaman, serbestçe geri alabilir" denmektedir. Yine açıklayıcı raporda hastanın bu yöndeki iradesinin, tedavi ya da müdahalenin kesilmesinin sonuçları kendisine açıkça bildirildiği taktirde hüküm ifade edebileceği kabul edilmektedir ${ }^{78}$. Bununla birlikte, bu kurala kimi istisnalar getirilebileceği öngörülmüştür. Bazı ülkelerde, başlamış bir müdaheleyi kesmenin hastaya büyük zarar verebileceği durumlarda tedaviye devam zorunluluğu öngörülen mesleki kurallar bulunabildiğ i dile getirilmektedir. $\mathrm{Bu}$ gibi düzenlemelerin söz konusu fıkra hükmüne aykırılık teşkil etmeyeceği savunulmaktadır ${ }^{79}$. Türk hukukunda, aralarında Umumi Hıfzısıhha Kanunu, Sitmanın İmhası Hakkında Kanun, Tibbi Deontoloji Nizamnamesi'nin de bulunduğu kaynaklarda tıbbı müdahale ya da tıbbi müdahaleye devam ödevinin düzenlendiği hükümler bulunmaktadır ${ }^{80}$. İlgilinin rızasını aramayan ve tıbbi müdahale görevi öngörülen bu gibi durumlarda Sözleşme'nin beşinci maddesinin ve bu maddenin üçüncü fıkrasının bir sorun yaratmayacağ düşünülmelidir.

\footnotetext{
${ }^{77}$ Aydınlatma yükümlülüğü ve aydınlanma hakkının kapsamı bakımından Türk öğretisinde Bkz. BAYRAKTAR, a.g.e., s.125; KEYMAN, Selahattin, "Hekimin Cezai Sorumluluğu", AÜHFD, C. 35, S. 1-4, 1978, s. 68; ÖZSUNAY, Ergun, "Alman ve Türk Hukuklarında Hekimin Hastayı Aydınlatma Ödevi ve İstisnaları", Sorumluluk Hukukundaki Yeni Gelişmeler V. Sempozyumu, Türk Hukukunda Hekimin Hukuki ve Cezai Sorumluluğu, MHAUM, Ankara 12/13 Mart, 1982, İstanbul, 1983, 31-59; ERMAN, Barış, Ceza Hukukunda Tıbbi Müdahalelerin Hukuka Uygunluğu, Ankara, Seçkin, 2003, s. 114 Ayrıca bkz. YENERER ÇAKMUT, Özlem, Tibbi Müdahaleye Rizanın Ceza Hukuku Açısından İncelenmesi, İstanbul, Legal, 2002, s. 226-227.

${ }^{78}$ Bkz. de WACHTER, a.g.e., s. 21.

${ }^{79}$ de WACHTER, a.g.e., s. 22.

${ }^{80}$ KATOĞLU, Tuğrul, "Hekimin Cezai Sorumluluğu", Doğum Hekimliği Maternal-Fetal Tıp'ta Etik ve Yasal Boyut, M. Sinan BEKSAÇ, Şebnem AKIPPEK ÖCAL, Tuğrul KATOĞLU, Zarife ŞENOCAK, Mehmet Ali ŞUĞLE, Ảnkara, Medikal Network, 2004, s. 63.
} 


\section{b. Özel Yaşam ve Bilgilendirilme Hakkı}

Sözleşme'nin 10. maddesinde sağlığa ilişkin kişisel verilerin korunması ve kişilerin sağlıklarına ilişkin verileri öğrenme hakkına yer verilmiştir. Onuncu maddenin ikinci fıkrasında herkesin, kendi sağlığı ile ilgili bilgileri öğrenme hakkı düzenlendikten sonra bireylerin, bilgilendirilmeme isteklerinin de gözetilmesi gerektiği hükme bağlanmaktadır.

\section{c. Özel Yaşam ile Kişisel Verilerin Korunması ve Türk Ceza Kanunu}

5237 sayılı TCK'nun 135. maddesinin son fıkrası uyarınca sağlık durumları da dahil olmak üzere kişisel bilgileri, kişisel veri olarak hukuka aykırı biçimde kaydedenlerin altı aydan üç yıla kadar hapis cezası ile cezalandırılması öngörülmektedir. TCK'nun 136. maddesinde ise, kişisel verilerin ifşaı ya da hukuka aykırı biçimde ele geçirilmesi cezalandırılmaktadır. TCK'nun 135, 136. maddelerinde düzenlenen fiillerin nitelikli haline 137. maddede yer verilmiştir. Maddenin (b) bendinde bu fiillerin, belli bir meslek ya da sanatın sağladığı kolaylıktan yararlanmak suretiyle işlenmesi durumunda verilecek cezanın yarı oranında artırılacağ hükme bağlanmaktadır. Buna göre, sağlık çalışanlarının bu fiillerin faili olması durumunda cezanın yarı oranında artırılması söz konusu olacaktır. Öte yandan, yine TCK'nun 139. maddesi uyarınca, özel hayatın gizliliği ve hayatın gizli alanına suçlar arasında 135, 136. maddelerde sayılanların soruşturulması ve kovuşturulmasının şikayete bağlı olmadığı belirtilmekle, bu fiillere karşı doğrudan soruşturma başlatılması yolu açılmıştır.

TCK'nun 140. maddesinde ise, bu fiillerin işlenmesi dolayısıyla tüzel kişiler bakımından, bunlara özgü güvenlik tedbirlerine hükmedileceği öngörülmektedir. Tüzel kişiler hakkında güvenlik tedbirleri TCK'nun 60. maddesinde düzenlenmiş olup, bu maddede belirtilen koşulların gerçekleşmesi durumunda ilgili tüzel kişiliğe de güvenlik tedbiri uygulanacağı açıktır. 60. maddenin birinci fıkrasında kamu kurumunun verdiği izne tabi faaliyet gösteren tüzel kişilerin izinlerinin iptali tedbirine yer verilmiştir. Tüzel kişiler bakımından öngörülen diğer tedbir türü ise, 2 . fıkrada yer verilen müsaderedir. TCK'nun müsadereye ilişkin hükümleri, tüzel kişi yararına işlenen suçlarda tüzel kişi bakımından da uygulanacaktır. $\mathrm{Bu}$ çerçevede, maddede öngörülen koşulların gerçekleşmesi durumunda iznin iptali ya da müsadere hükümleri, sağlığa ilişkin verileri saklamakla yükümlü bulunan ve özel hukuk tüzel kişiliğini haiz sağlık kuruluşlarına uygulanabilecektir.

$\mathrm{Bu}$ yönüyle anılan hükümler, hem kişisel verilerin korunmasına ilişkin Avrupa Sözleşmesi'nin de aralarında bulunduğu uluslararası belgeler hem de başta Anayasa olmak üzere özel yaşamın gizliliğini güvence altına almayı 
amaçlayan diğer düzenlemeler ile birlikte düşünülmeli, özel yaşamın gizliliğinin ve sağlıkla ilgili kişisel bilgilerin de korunması bakımından İnsan Hakları ve Biyotıp Sözleşmesi'nde öngörülen müeyyide getirme yükümlülüğünün karşılandığı sonucuna varılmalıdır.

\section{ç. İnsan Genomunun Korunması ve Bilimsel Araştırmalar}

Sözleşme'nin 13. maddesi ile insan altsoylarının genetik yapısını değiştirmeye yönelik bilimsel araştırmalar yasaklanmaktadır ${ }^{81}$. Genetik çalışmalar, ancak sağlık ya da tedavi amacıyla yürütülebiliir ${ }^{82}$. Biyotıp alanında uluslararası oydaşmanın gerçekleştiği temel konulardan biri, genetik yapıyı bozucu müdahalelerin yasaklanmasıdır. UNESCO Bildirgesi'nin 24. maddesinde bu tür müdahaleler yasaklanmıştır ${ }^{83}$.

Biyotıp alanına ilişkin temel bazı konuların insan hakları çerçevesine yerleştirilmeleri son derece önemlidir. Bu noktada genetik araştırmalara ilişkin temel kuralların insan türünün kimliğini, özelliklerini korumaya hizmet ettiği unutulmamalıdır. İnsan türünün, zararlı müdahalelere, salt mali ya da bilimsel yararlara feda edilmesi önünde uluslararası hukuk engel oluşturacaktır ${ }^{84}$. Biyotıp alanındaki oydaşma belli başlı birkaç konu ile sınırlı görünmekle birlikte genetik alanındaki ilerlemeler karşısında temel bazı ilkelerin kabul edildiği saptanmalıdır. Bu koruyucu ilkeler, aydınlatılmış hastanın rızası, ayrımcılık yasağı, sosyal adalet ile genetik verilerin korunmasidir ${ }^{85}$.

Genetik araştırmalarda da hastanın ya da ilgilinin rızası gereklidir. Bununla birlikte salt rızanın varlığı da yeterli olmayıp, Sözleşme'nin 12. maddesinde genetik teşhise yönelik testlerin, “..sadece sağllk amaçlartyla veya sağlık amaçlı bilimsel araştırma için ve uygun genetik danışmada bulunmak şartıyla..” yapılabileceği hükme bağlanmıştır. O halde rıza yeterli olmayıp ayrıca genetik danışma da ihmal edilmemelidir ${ }^{86}$.

Bazı hastalıkların tedavisine yönelik genetik müdahaleler bakımından esaslı bir etik sorun bulunmadığ savunulmaktadır $^{87}$. Avrupa Konseyi İnsan Hakları ve Biyotıp Sözleşmesi'nin 13. maddesi ile gelecek nesillerin genetik yapısının geri döndürülemez biçimde dönüşmesine, bozulmasına yol açacak müdahaleler yasaklanmaktadır. Madde ile önleme, teşhis ve tedavi amacıyla sınırlı olarak insan genomunu değiştirmeye yönelik müdahale kabul

${ }^{81}$ WINTER, a.g.e., s. 73.

${ }^{82}$ KNOPPERS, Bartha M.; Rosario M. ISASI, "Regulatory Approaches to Reproductive Genetic Testing", Human Reproduction, Vol. 19, No. 12, 2004, s. 2699.

${ }^{83}$ ANDORNO, a.g.e., par. 14 ve 16.

${ }^{84}$ ANDORNO, a.g.e., par. 11.

${ }^{85}$ ANDORNO, a.g.e., par. 12.

${ }^{86}$ HONNEFELDER, a.g.e., par. 19.

${ }^{87}$ ANDORNO, a.g.e., par. 15. 
edilmiştir. Bu sınırlar dışında kaldı ̆̆ı açık olan, öjenik amaçlı genetik müdahaleler, genetik teknolojinin kötüye kullanılması olarak değerlendirilmekte ${ }^{88}$, dolayısıyla 13. maddeye aykırılık teşkil etmektedir.

Sözleşme'nin 11. maddesinde yer alan ayrımcılı̆̆ın önlenmesi hükmü, iş yaşamında, sigorta hukuku alanında, bazı genetik özelliklere sahip kimselerin ayrımcılığa tabi tutularak, bilimsel gelişmelerden yarar yerine zarar görmelerinin önüne geçmeyi amaçlamaktadır ${ }^{89}$. Sözleşme'ye ilişkin açıklayıcı raporda, genetik testler dolayısıyla ortaya çıkan en önemli sorun noktalarından birinin bu uygulamaların bir tercih ve ayrımcılık aracına dönüşme tehlikesi olduğu belirtilmektedir ${ }^{90}$. Sözleşme'nin hazırlık çalışmalarına da etki eden bu sorunun giderilmesi bakımından sevkedilen 11. maddenin yanı sıra 12. maddede genetik testlerin sadece sağlık ve tedavi amacıyla yapılabileceği hükme bağlanmıştır. Yine açıklayıcı raporda istihdam tercihleri ve sigorta poliçelerinin hazırlanmasının sağlık amacı oluşturmadığı açıkça dile getirilmektedir ${ }^{91}$. Bu doğrultuda, sigorta şirketinin genetik test yaptırmayı koşul olarak ileri süremeyeceği, buna karşın ileri sürülen böyle bir koşulun ilgili tarafından reddedilmesinin poliçeyi etkilememesi gerektiği belirtilmektedir ${ }^{92}$. Bu yönüyle hüküm, Avrupa Temel Haklar Şartı'nın 21. maddesine de nüfuz etmiş, çeşitli ulusal hukuk düzenlerinde etkiler doğurmuştur ${ }^{93}$. Ayrımcılık yasağına UNESCO Bildirgesi'nin 12. maddesinde de yer verilmektedir ${ }^{4}$. Ayrımcılığın önlenmesinde genetik veri tabanlarının ve genetik verilerin korunması konusunda ayrıca Avrupa İnsan Hakları Sözleşmesi'nin din ve inanç özgürlüğüne ilişkin 9. maddesinin de devrede olduğu savunulmaktadır ${ }^{95}$.

Öte yandan genetik araştırma sırasında elde edilen kişisel genetik verilerin saklanması konusunda UNESCO Genom ve İnsan Hakları Bildirgesi ve UNESCO İnsan Genetik Verileri Bildirgesinde de hüküm bulunmaktadır. UNESCO Genel Kurulu'nda 2003 yılında kabul edilen Bildirge'nin 9. maddesi hükmü uyarınca bu tür verilerin bilimsel amaçla kullanılabilmesi için dahi ilgilinin rızası şarttır. Bu tür bilgilerin bilim

${ }^{88}$ ANDORNO, a.g.e., par. 14 ve 16 ; WINTER, a.g.e., s. 75.

${ }^{89}$ PICIOCCHI, a.g.e., s. 11; McHALE, J.V., "Regulating Genetic Databases: Some Legal and Ethical Issues", Medical Law Review, No. 12, Spring 2004, Oxford University Press., s. 76, 77; SKENE, a.g.e., s. 16: HONNEFELDER, a.g.e., par. 16.

${ }^{90}$ Convention for the protection of Human Rights and dignity of the human being with regard to the application of biology and medicine: Convention on Human Rights and Biomedicine, http://conventions.coe.int/Treaty/EN/Reports/Html/164.htm par. 74, (erişim tarihi 18.11.2005).

${ }^{91}$ SKENE, a.g.e., s. 17; Rapport explicatif à la Convention pour la protection des droits de l'Homme et de la dignité de l'être humain à l'égard des applications de la biologie et de la médecine (Rapor), http://infodoc.inserm.fr/ethique/Ethique.nsf, par. 86; KNOPPERS ve ISASI, a..g.e., s. 2699.

${ }^{92}$ SKENE, a.g.e., s. 17; Rapor, par. 86.

${ }^{93}$ PICIOCCHI, a.g.e., s. 11; McHALE, a.g.e., s. 76, 77

${ }_{95}^{94}$ McHALE, a.g.e., s. 78; SKENE, a.g.e., s. 17.

${ }^{95}$ McHALE, a.g.e., s. 83 . 
insanları arasında devri için de bu kural geçerlidir ${ }^{96}$. Öte yandan Avrupa İnsan Hakları Sözleşmesi'nin özel yaşamın gizliliğini koruyan 8. maddesi de bu alandaki veriler ve veri tabanlarının korunması bakımından önemli bir kaynaktır ${ }^{97}$. Söz konusu yasak, bilim insanları ile de sınırlı olmayıp aile fertlerine kadar uzanmaktadır. İlgilinin onayı olmadan, aile fertleriyle dahi bu verilerin paylaşılmaması gerekir ${ }^{98}$. Sadece genetik veriler değil, genel anlamda bir hastalığa ilişkin verilerin aile fertleriyle dahi paylaşılmamasının kabul edilebildiği görülmektedir ${ }^{99}$.

Yukarıda da dile getirildiği gibi, Sözleşme'nin 10. maddesinin 2. fıkrası hükmü uyarınca, kişiler sağlık alanında ve kendileri ile ilgili bilgi ve verileri öğrenme hakkına sahiptir. Genetik veriler de bu çerçevede kabul edilmektedir. Yine daha önce belirtildiği üzere, ilgilinin, bu konuda bilgilenme hakkını kullanmayabileceği de aynı fıkrada kabul edilmiştir. Kendi geleceğini “ümitsiz” gördüğü bir vakada kişinin genetik veriler de dahil olmak üzere bilgilenme hakkını kullanmamak hususunda irade beyanında bulunması mümkündür. Benzer düzenlemeye UNESCO Bildirgesinin 5. maddesinde de yer verilmiştir ${ }^{100}$. Türk öğretisinde, hastanın bilgilenme ya da aydınlanma hakkından vazgeçebileceğini savunan yazarlar vardır. Bu görüşe göre, hasta aydınlatılma hakkından vazgeçebilir. Aydınlatılma bir hak olduğuna göre, hak sahibi, bu hakkı kullanmak istemeyebilir. Ancak vazgeçme yönündeki iradenin açık ve hekim tarafından anlaşılabilir olması gereklidir ${ }^{101}$. Bu noktada, amansız bir hastalığa ilişkin genetik verileri öğrenmemek yolundaki irade beyanının açıkça yapılması ve hekim tarafından anlaşılabilir olması gerekmektedir. Çeşitli ülke hukuklarında bu hükümlere yer verilebilmektedir ${ }^{102}$.

Altsoyun genomunda değişiklik yapılması sonucunu doğurmakla birlikte bir hastalığın gelecekte tamamen ortadan kaldırılması amacıyla yapılan çalışmaların yasaklanmaması yönünde görüşler mevcuttur ${ }^{103}$. Onüçüncü maddede, tedavi amaçlı genom değiştirilmesi, altsoy genomunda değişiklik yapılmaması koşuluna bağlanmıştır. Amaç, bir hastalığın tamamen yok edilmesi de olsa, insan türünün özelliklerinin korunması, etik ve insan hakları bakımından temel bir değer olarak anlaşılmaktadır. Amaca önem veren ve yasağın alanının daraltılmasını savunanlara karşılık, tüm insan topluluğundan kötücül genomların ayıklanmasının ancak bir ütopya

${ }^{96}$ JOHNSTON, Carolyn; Jane KAYE, "Does the Biobank Have a Legal Obligation to Feedback Individual Findings to Participants?", Medical Law Review, No. 12, Autumn 2004, Oxford University Press, s. 255; McHALE, a.g.e., s. 77.

${ }^{97}$ McHALE, a.g.e., s. 78,83 .

${ }^{98}$ SKENE, a.g.e., s. 21.

${ }_{99}$ ERMAN, a.g.e., s. 119; terapötik amaçlarla aile fertlerine bilgi verilmemesi konusunda da bkz. ÖZSUNAY, a.g.e., s. 47.

${ }^{100}$ McHALE, a.g.e., s. 91; HONNEFELDER, a.g.e., par. 17.

${ }^{101}$ ERMAN, a.g.e., s. 116, 117; YENERER ÇAKMUT, a.g.e., s. 233.

${ }^{102}$ PICIOCCHI, a.g.e., s. 11.

${ }^{103}$ ANDORNO, a.g.e., par. $18,19$. 
olabileceği, bunun bin yıllara yayılacağı, öte yandan kitlesel genetik müdahalelerin ahlaken son derece sorunlu olduğu dile getirilmiştir ${ }^{104}$. Yine gelecek nesillerin biyo özelliklerinin önceden belirlenmesi, "iyi”" ve "kötü" değerlendirmeleri doğrultusunda altsoyların biyolojik koşullandırılması, yeni nesillerin kendilerinden çok öncekilerin değerlendirmeleri doğrultusunda belirlenmelerini, bir "nesillerarası tiranlığın" oluşmasını sonuçlayabilecektir. İnsan, bu tür müdahalelerle özneden nesneye, tasarım ürünlerine dönüşsebilecektir ${ }^{105}$.

\section{d. İnsan Genomu Üzerinde Bilimsel Çalışmalar, Tarama Testleri ve Türk Ceza Kanunu}

Sağlık alanına ilişkin kişisel bilgilerin korunması ve hukuka aykırı biçimde kaydedilmesinin önlenmesi amacına yönelik cezai düzenlemelere yukarıda değinilmişti. Gerçekten genetik veriler de korunması gerekli kişisel bilgiler arasında yer almaları dolayısıyla bu cezai korumadan yararlanacaktır. Bu yönüyle, TCK'nun 135, 136 ve 137. maddelerinin kişisel genetik bilgilerin cezaen korunması bakımından da hüküm ifade etmesi gerekir. Diğer kişisel veriler arasında sağlığa ilişkin kişisel verilerin hukuka aykırı biçimde kaydedilmesini yasaklayan 135. maddenin yanı sıra bu verilerin ifşaını suç sayan 136. madde ile bu fiillerin nitelikli hallerini düzenleyen 137. madde hükümlerinin bu konuda da uygulanabileceği açıktır.

Yine TCK'nun 140. maddesinde tüzel kişilere güvenlik tedbiri uygulanması yolunu açan düzenlemelerin genetik verilerin korunması bakımından geçerli olduğu da açıktır. Bu çerçevede özel hukuk tüzel kişiliği haiz olup da genetik tanıya yönelik testler yapan kurumlar bakımından, bu verilerin ifşaı dolayısıyla bir menfaat sağlandığı durumlarda, iznin iptali ile kazanç müsaderesi tedbirlerinin uygulanması olasılığı vardır.

Bunlara ek olarak Sözleşme'nin 11. maddesi ile yasaklanan genetik kalıtıma dayalı ayrımcılık yasağının cezai teminatı olması dolayısıyla TCK'nun 122. maddesinin ele alınmasında yarar bulunmaktadır. 122. maddenin ilk fıkrasında "Kişiler arasında dil, ırk, renk, cinsiyet, özürlüilük, siyasi düşünce, felsefi inanç, din, mezhep ve benzeri sebeplerle ayrım yaparak" taşınır ya da taşınmaz mal edinilmesine, devrine, bir hizmetin icrasına katılmaya ya da bir hizmetten yararlanılmasına ya da işe alınmaya engel olunması suç sayılmaktadır. Aynı maddenin (c) bendi ile ayrıca, ayrımcılık yaparak kişinin olağan bir ekonomik etkinlikte bulunmasına engel olunamayacağı da hükme bağlanmaktadır. Ayrımcılık kenar başlığı altında düzenlenen bu maddede yer verilen düzenlemelerin, Sözleşme ile güvence altına alınmaya çalışılan, genetik verilerin ayrımcılık amacıyla kullanılması yasağını teminat altına aldığını söylemek uygun olacaktır.

${ }^{104}$ ANDORNO, a.g.e., par. 19.

${ }^{105}$ ANDORNO, a.g.e., par. 20; HONNEFELDER, a.g.e., par. 17.. 


\section{e. Biyoloji ve Tıp Alanında Bilimsel Araştırmalara İlişkin Temel İlkeler ve Türk Ceza Kanunu'nda Düzenlenen Çocuk Üzerinde Deney}

Sözleşme'nin 15. maddesinde biyoloji ve tıp alanında bilimsel araştırmanın Sözleşme hükümleri ile insanın varlığını korumaya yönelik diğer yasal düzenlemelere uygun olmak koşuluyla serbestçe yürütülebileceği hükme bağlandıktan sonra, 16. maddede, üzerinde bilimsel araştırma yapılan kişilerin korunmasına ilişkin temel kurallar sevkedilmiştir. İnsan üzerinde araştırma, ancak maddede belirtilen koşulların gerçekleşmesi halinde mümkün olabilecektir. İnsan üzerinde deney ve denemeleri de kapsayan bu düzenlemelerin yanı sıra, kuşkusuz TCK'nda yer verilen insan ve çocuk üzerinde deney ve denemeye ilişkin hükümler de hukukumuzda konunun sınırlarını çizmektedir. TCK'nun bu hükümlerine, Sözleşme hükümleri ışığında olmak üzere aşağıda değinilecektir. Sözleşme'nin 16. maddesine göre, insan üzerinde araştırma yapılabilmesi için, insanın sağlığı bakımından aynı etkinlikte başka bir yöntemin bulunmaması gerekmektedir.

Aynı maddenin (ii) bendi uyarınca araştırmanın yol açabileceği tehlikeler ile araştırmadan beklenen yarar arasında oran bulunması, (iii) bendi uyarınca araştırmanın önem ve bilimsel değerinin çok disiplinli zeminlerde değerlendirilmesi, etik komitelerce de onaylanmass ${ }^{106}$ (iv) üzerinde araştırma yapılanların bu alana ilişkin kanuni hak ve güvenceler konusunda bilgilendirilmeleri, (v) belgelendirilmiş ve açık rızanın bulunması gerekmektedir. Rıza, her zaman ve serbestçe geri alınabilecektir.

Sözleşme'nin 17. maddesinde ise, rıza yeteneği bulunmayanların korunmasına ilişkin temel kurallara yer verilmiştir. Rıza yeteneği bulunmayanlar üzerinde araştırma, ancak maddede belirtilen koşulların varlığı durumunda söz konusu olabilecektir. Bu koşullar arasında en önemli olanlardan biri, araştırma sonuçlarının ilgilinin sağlı̆̆ı üzerinde doğrudan yarar sağlama beklentisinin varlı̆̆ıdır. Madde'nin (ii) bendinde açıkça aranan doğrudan yarar koşulunun gerçekleşmemesi durumunda, rıza yeteneği bulunmayanlar üzerinde tıbbi araştırma yapılması mümkün olmayacaktır. Bu hüküm özellikle TCK'nun 90 maddesinde düzenlenen ve çocuk üzerinde deneye belli koşulların varlığı durumunda izin veren hükmün uygulanabilirliği bakımından önemlidir.

Sözleşme'nin 17. maddesi hükmü gereği, doğrudan menfaatine

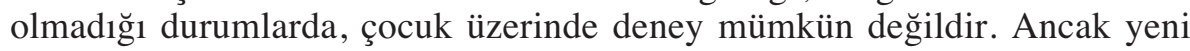
ilaçların ya da tedavi yöntemlerinin Kanun'da belirtilen koşullar çerçevesinde denenmesi mümkün olabilir. Bu gibi durumlar dışında çocuk üzerinde deneye belli koşullar dahilinde izin veren TCK'nun 90. maddesi hükmünün uygulanabilirliğinin değerlendirilmesi gerekmektedir.

\footnotetext{
${ }^{106}$ SKENE, a.g.e., s. 23.
} 
TCK'nun 90. maddesinin ilk fıkrasında insan üzerinde hukuka aykırı bilimsel deney yapılması suç sayılarak cezalandırılmıştır. İkinci fıkrada ise, insan üzerinde bilimsel deney yapılabilmesi için aranacak koşullar yedi bent altında sayılmıştır. Bu koşulların varlığı durumunda insan üzerinde bilimsel deney suç oluşturmayacaktır. Bu yönüyle hüküm, bu koşulların gerçekleşmesine bağlı olarak bilimsel deney yapma yetkisi vermektedir.

TCK'nun 90. maddesinin 3. fıkrasında ise, çocuk üzerinde bilimsel deney konusu düzenlenmiştî ${ }^{107}$. Çocuk üzerinde bilimsel deneyin suç teşkil etmemesi için, erişkinler bakımından bir önceki fıkrada kabul edilen bilimsel deney koşullarının ağırlaştırıldığı görülmektedir. Buna göre, ikinci fıkrada belirlenen koşullara ek üç koşul daha kabul edilmiştir. Bunlardan ilki, 3 . fıkranın (a) bendinde düzenlenmiştir. Bent hükmü uyarınca, "Yapılan deneyler sonucunda ulaşılan bilimsel verilerin, varllmak istenen hedefe ulaşmak açısından bunların çocukların üzerinde yapılmasını gerekli kılması" koşulu gerçekleşmelidir. Buna ek olarak (b) bendinde rıza yeteneği bulunan çocuğun kendi rızası ile anne ve babasının ya da kanuni temsilcisinin rızası aranmaktadır. Nihayet (c) bendi uyarınca, ikinci fıkraya göre deneye izin verilmesi konusunu takdir etmek üzere kurulacak kurullarda mutlaka çocuk sağlığı ve hastalıkları uzmanı bulunacaktır. Bu koşullar gerçekleşmeden, sadece ikinci fıkrada belirtilen koşulların gerçekleşmesi, çocuk üzerinde deneyi suç olmaktan kurtarmayacaktır. Burada üzerinde durulması gereken, bu koşullardan söz konusu (a) bendinde düzenlenmiş olanıdır. "Yapılan deneyler sonucunda ulaşılan bilimsel verilerin, varllmak istenen hedefe ulaşmak açısından bunların çocukların üzerinde yapılmasını gerekli kılması" ifadesinden ne anlaşılmalıdır? Kanımızca bent hükmü ile doğrudan çocuğun sağlıkla ilgili menfaatinin korunduğunu söylemek güçtür. Bilim ve toplumun menfaati kastediliyor ise, bu yetkinin, Avrupa İnsan Hakları ve Biyotıp Sözleşmesi'nin insanın önceliğini düzenleyen 2. maddesi, rıza yeteneği bulunmayanlar üzerinde bilimsel araştırmayı düzenleyen 17. maddesinin birinci fıkrasının ii) numaralı paragrafı ve Türkiye'nin taraf olduğu uluslararası insan hakları sözleşmelerine diğer iç hukuk hükümleri karşısında üstünlük tanıyan Anayasa'nın 90. maddesi karşısında bir geçerliliği bulunmadığını söylemek gerekir.

${ }^{107}$ TBMM Adalet Alt Komisyonu'nun Kabul ettiği metinde çocuk üzerinde deney her halde yasaklanmıştı. Genel Kurul'daki görüşmeler sırasında 15.09.2004 tarihli önerge ile belli koşullara bağlı olarak çocuk üzerinde deney yapılmasına olanak tanıyacak biçimde madde değistirilmiș, daha sonra Kanun henüz yürürlüğge girmeden 31.03.2005 tarihli kanun ile bu koşullara bir üçüncüsü olan çocuk hastalıkları uzmanının katılması da eklenerek madde son biçimini almıştır. Çocuk üzerinde deney yapılmasına olanak tanıyan değiş̧iklik önergesinin gerekçesinde Çocuk Haklarına Dair Sözleşme hükümlerine yer verildiğ belirtilmektedir. (ÖZGENÇ, İzzet, Gerekçeli Türk Ceza Kanunu, Ankara, Seçkin, 2004, s. 187). Sözleşme hükümleri arasında doğrudan çocuk üzerinde deneye ilişkin bir düzenleme bulunmamaktadır. Özellikle 24 vd. Maddelerinde Sözleşme'ye taraf devletlerin çocuklara sağlanacak tıp hizmetleri bakımından yükümlülüklerine yer verilmekte, bu konuda en yüksek standarda ulaşılması beklenmektedir. 
TCK'nun 90. maddesinin 3. fıkrasında öngörülen hükümler Anayasa'nın 90. maddesinin son fıkrası uyarınca Sözleşme ile uyum içinde olduğu sürece uygulanabilir. Sözleşme'nin, bir insan hakları sözleşmesi olduğu yinelenmelidir. Yeni TCK, Sözleşme'ye taraf olunmasından ve Sözleşme'nin iç hukukun parçası olmasından sonra yürürlüğe girmiş olsa da Anayasa'nın 90. maddesinin son fıkrası hükmü uyarınca iki hüküm arasındaki çelişki Sözleşme lehine çözülecektir. Bu çerçevede, katı koşullara bağlanmış dahi olsa çocuk üzerinde deney yapılmasına olanak veren TCK'nun 90. maddesi hükmü, bu yönüyle ya hiç uygulanamayacak ya da kısmen uygulanabilecek ve çocuğun sağlığı üzerinde doğrudan ve gerçek bir yarar sağlayamadığı sürece çocuk üzerinde deney yapılması mümkün olmayacaktır. Bununla birlikte, öngörülen koşulların gerçekleşmesi halinde 4. fikrada yer alan tedavi amaçlı denemelerin çocuklar üzerinde uygulanması mümkündür. Zira tedavi, çocuğun sağlığı bakımından gerçek ve doğrudan yarar sağlayabilecektir.

Yukarıda, "İnsan Hakları ve Biyotıp” başlığı altında doğrudan yarar kavramının içeriğinin belirlenmesine ilişkin güçlüklere işaret edilmekle birlikte, bir küçüğün doğrudan tedavisi amacına yönelik olmayan ve daha ziyade tıp bilimi ile toplumun menfaatlerine hizmet eden bir deneyin yapılması kanımızca mümkün değildir. Sözleşme hükümleri uyarınca, çocuğun doğrudan yararı olmadığı sürece TCK'nun 90. maddesinde verilen yetkinin sonuç doğuramaması gerekir.

Öte yandan TCK'nda, belli koşullar dışında kalan insan üzerinde tıbbi deneyi yasaklayan tek hüküm 90. maddede yer almamaktadır. Bunun dışında TCK'nun insanlığa karşı suçları düzenleyen 77. maddesinin birinci fıkrasının (e) bendinde, siyasal, felsefi, rrksal ya da dinsel saiklerle toplumun belli bir kesimine (sivil nüfus) ${ }^{108}$ üye kişiler üzerinde deneyler yapılmasını cezalandırmaktadır. Buna göre, maddede belirtilen koşullar içinde insan üzerinde deney insanlığa karşı suç olarak nitelenebilecektir.

\section{f. Tüpte Embriyonlar Üzerinde Araştırma}

Sözleşme'nin 18. maddesi, tüpte embriyonlar üzerinde araştırmayı yani in vitro embriyonlar üzerindeki bilimsel çalışmaları düzenlemektedir. Sözleşme'nin "Tüpte embriyonlar üzerinde araştırma" başlıklı 18. maddesinin ilk fikrasında "Hukukun embriyon üzerinde tüpte araştırmaya izin vermesi halinde, embriyon için uygun koruma sağlanacaktır" ifadesine yer verilmekte, ikinci fıkrada ise, "Sadece araştırma amaçlarıyla insan embriyonlarının yaratılması yasaktı" denmektedir. Benzer düzenleme, UNESCO bildirgesinde yer almaktadır. Ayrıca A.B. Temel Haklar Şartı'nda,

${ }^{108}$ TEZCAN, Durmuş; Mustafa Ruhan ERDEM, Murat ÖNOK, Teorik ve Pratik Ceza Özel Hukuku, Ankara, Seçkin, 2006, s. 58, 59. 
insan klonlama yasağına uyulması gerektiğine dikkat çekilmiştir ${ }^{109}$. Maddenin yorumu bakımından temel sıkıntılar, ilk fıkradaki "embriyon için uygun koruma" ifadesinin gerçek ve doğru anlamını tespit ile, ikinci fıkradaki kısıtlayıcı hüküm dolayısıyla tedavi amaçlı embriyonik kök hücre çalışmalarının yasaklanıp yasaklanmadığıdır. Özellikle ikinci fıkra hükmüne ilişkin tartışmalar özel bir öneme sahiptir. Sorunun temelinde inanç etkenine dayalı tartışmalar yattığından nihai bir çözümün yakın olduğunu söylemek olanaksızdır ${ }^{110}$.

İlk fıkrada dile getirilen "uygun koruma" deyiminin doğru ve gerçek anlamı nedir? Uygun koruma deyiminin belirsiz olması, Sözleşme’ye yönelik temel eleştiriler arasında yer almakla birlikte, bu hüküm ile minimal bir koruma sağlandığ düzenlerine bırakıldığı dile getirilmektedir ${ }^{111}$. Öğretide, uygun koruma deyiminden, embriyona saygıll, insan onuruna uygun, keyfilikten uzak bilimsel araştırmayı anlayan yazarlar vardır ${ }^{112}$.

Uluslararası toplumun biyotıp alanında üzerinde oydaştı̆̆ı başlıca konulardan biri, insan klonlaması yasağıdır (human reproductive cloning). Hukuk düzenleri genellikle bilimin ve biyotıp alanındaki gelişmelerin gerisinde kalır. Ancak bu tür klonlama bakımından, ilk defa gelecekte gerçekleştirilmesi olası biyotıbbi çalışmaların yasaklanması söz konusu olmaktadır ${ }^{113}$. İnsan klonlaması bakımından genel kabul gören bu yasak birçok ülke mevzuatında yerini almış, hatta çeşitli ülkelerde suç olarak tanımlanarak ceza sorumluluğu öngörülmüştür ${ }^{114}$. İnsan onuru ve insan kimliği, insan klonlaması yasağında da karşımıza çıkan kavramlardır. Klonlamayı gerçekleştirenlerin klonlar üzerinde meşru görülmesi mümkün olmayan bir iktidar ya da nüfuz oluşturması kaçınılmazdır ve bu da insanların araçlaştırılması anlamına gelir. Öte yandan insan klonlamasının kabulüyle klonlar, biribirlerinin yerine ikame olunabilir kopyalardan farksız muamele görecektir. Bu durumun, insan onuru ve kimliğine zarar vereceği açıktır $^{15}$. İnsan klonlama yasağına ilişkin Sözleşme'ye ek protokolün başlangıç kısmındaki, klonlamanın insanı araçsallaştıracağı, bunun insan onuruna aykırı olduğu ve biyoloji ile tıbbın kötüye kullanılması anlamına

${ }^{109}$ WINTER, a.g.e., s. 76; PATTINSON, Shaun D., "Reproductive Cloning: Can Cloning Harm the Clone?" Medical Law Review, No. 10, Autumn 2002, s. 302.

${ }^{110}$ GUNNING, Jennifer, "Article 18 of the European Biomedicine Convention: What Impact on Assisted Reproduction?", European Journal of Health Law, No. 11, 1999, Kluwer Law International, s. 165 vd. ve 168; bu konuda ayrica MANUEL, C., HAIRON, D., AUQUIER, P., REVIRON, D., GIOCANTI, D., TERRIOU, P., PELLISSIER, V., SAN MARCO J.L. a.g.e., s. 58, 59

${ }^{111}$ HALLIDAY, Samantha, "A Comparative Approach to the Regulation of Human Embryonic Stem Cell Research in Europe”, Medical Law Review, No. 12, Spring 2004 Oxford University Press, s. 45.

${ }^{112}$ Bkz. HALLIDAY, a.g.e., s. 45.

${ }^{113}$ ANDORNO, a.g.e., par. 14.

${ }_{114}^{114}$ Bkz. PATTINSON, a.g.e., s. 297.

${ }^{115}$ ANDORNO, a.g.e., par. 27; WINTER, a.g.e., s. 75; PATTINSON, a.g.e., s. 306. 
geleceği ifade edilmiştir ${ }^{116}$. Sözleşmede insan klonlaması yasağına hizmet eden en azından üç hüküm olduğu dile getirilmiştir. Bunlar, Sözleşme'nin insan onuru ve insan kimliğini düzenleyen birinci, araştırma amaçlı in vitro embriyon üretilmesini yasaklayan 18. maddesi ve altsoyun genetik yapisını değiştirmeyi yasaklayan 13. maddeleridir ${ }^{117}$.

Biraz yukarıda belirtildiği gibi, 18. maddenin kapsamı konusunda tartışmalar vardır. İngiltere' de bu hüküm tartışılırken farklı görüşler ileri sürülmüş̧ür. $\mathrm{Bu}$ çerçevede, maddede yer alan "Sadece araştırma amaçlarıyla insan embriyonlarının yaratılması yasaktır" ifadesinin terapötik klonlamayı yasakladığı ya da tam aksine buna izin verdiği yolunda farklı yorumlara rastlanmıştır ${ }^{118}$. Onsekizinci maddenin ikinci fıkrasının, embriyonik kök hücre çalışmalarını yasakladığını savunan yazarlardan bazıları, bunun evrensel olarak kabul edilmesinin mümkün olmadığı kanısındadır ${ }^{19}$. Onsekizinci maddenin embriyonik kök hücre araştırmaları bakımından mutlak bir engel oluşturduğunu savunan bazı yazarlar, Sözleşme'ye taraf olup da bu maddenin uygulanması konusunda çekince koymayan ülkelerde bu yönde tedavi amaçlı bilimsel araştırmaların yapılamayacağı kanısındadır ${ }^{120}$. Türkiye Büyük Millet Meclisi, Sözleşme'nin onaylanmasını uygun bulurken sadece organ nakli ile ilgili 20. maddeye ilişkin çekince koymuş, bununla birlikte 18. maddeye ilişkin herhangi bir çekince uygun bulma kanununda yer almamıştır. Bu hüküm nedeniyle Sözleşme'ye taraf olmayan devletler de bulunmaktadır ${ }^{121}$. Hükmün tamamen yasakçı olarak anlaşılması durumunda üreme tıbbı, ve kimi hastalıklarla mücadele bakımından yapılacak bilimsel araştırmaların devam etmesi mümkün olmaktan çıkacaktır ${ }^{122}$. Çok tartışmalı olmakla birlikte embriyonik kök hücre araştırmalarının, aralarında Parkinson, Alzheimer ve şeker hastalıklarının da bulunduğu çeşitli tıbbi sorunların tedavisi açısından önemli

${ }^{116}$ PATTINSON, a.g.e., s. 306 .

${ }^{117}$ WINTER, a.g.e., s. 75.

${ }^{118}$ PICIOCCHI, a.g.e., s. 8; GUNNING, a.g.e., s. 166.

${ }^{119}$ GUNNING, a.g.e., s. 166; ayrica bkz. ROSEANU, Henning, "Yeniden Canlı Üretimi, Tedavi Edici Klonlama Tartışmaları ve Alman Kök Hücre Kanunu”, çev. Hakan Hakeri, Karşılaştırmalı Güncel Ceza Hukuku Serisi 2, Tıp ve Ceza Hukuku, Ankara, Seçkin, 2004, s. 68 vd.

${ }^{120}$ GUNNING, a.g.e., s. 168.

${ }^{121}$ HALLIDAY, a.g.e., s. 44; GUNNING, a.g.e., s. 168.Bir görüşe göre, Sözleşme’ye taraf olma tarihinden önce ulusal mevzuatında tedavi amaçlı embriyonik kök hücre çalışmalarına olanak tanıyan ülkeleri bu Sözleşme etkilemeyecek, bu ülkelerdeki çalışmalar devam edecektir (Gunning, a.g.e., s. 168). Bununla birlikte Türk Anayasa Hukuku dikkate alındığında, Sözleşme tarihinden önce bu yönde Türk hukukunda bir düzenleme yapılmış olsaydı bile, Anayasa'nın 90. maddesi uyarınca usulüne uygun olarak kabul edilmiş bir uluslararası sözleşme iç hukukun parçası haline geleceğinden sonraki kanun oluşturacak ve önceki ilgili kanunu ilga edecekti. Öte yandan, iç hukukumuzun parçası haline gelmesinden sonra, Sözleşme'nin 18. maddesine aykırı bir düzenleme yapılması durumunda da bu sefer Anayasa'nın 90. maddesinin son fıkrası hükmü uyarınca insan haklarına ilişkin sözleşmelere üstünlük tanındığından sonraki yetki veren kanunun da uygulanma kabiliyeti bulunmayacaktır.

${ }^{122}$ GUNNING, a.g.e., s. 168. 
katkılar sağlayabileceği savunulmaktadır. Özellikle terapötik klonlama suretiyle otolog transplantasyonda, bünyenin nakli reddetmesi tehlikesinin azalması dolayısıyla sağlanan tıbbi yarar, kök hücrenin alınması sırasında embriyonun tahrip edilmesi zorunluluğu karşısında etik tartışmaların merkezine oturmuştur ${ }^{123}$. Bu tartışmalarda, embriyon üzerinde araştırma yapılıp yapılamayacağı, eğer yapılabilecekse hangi devrede ve hangi yöntemlerle bu araştırmaların yürütülebileceği sorunlarının çözülmesi gerekmektedir. 1980 ve 1990'larda özellikle üreme tıbbı ve dolayısıyla üremeye yardımcı teknikler alanında embriyonik kök hücre çalışmaları dikkat çekmiş, tıp biliminin gelişimine koşut olarak, transplantasyon gibi üreme tıbbından çok farklı alanlarda da bu araştırmalar yoğunlaşmıştır. $\mathrm{Bu}$ alan değişikliklerine karşın temel sorunsallar varlığını korumuştur. Embriyonun niteliği üzerine etik ve hukuksal tartışmalar yapılagelmektedir ${ }^{124}$. İnsan embriyonu, kişi adayı, haklara sahip kişi ya da bir laboratuar malzemesi midir? Üremeye yardımcı tekniklerin uygulanması dışındaki amaçlarla in vitro embriyonların oluşturulması ve bunlar üzerinde bilimsel araştırma yapılmasının insan onuru merkezli bakış açısından konumu belirlenmelidir ${ }^{125}$. Avrupa Birliği Avrupa Komisyonu bir çalışma metninde, bu konuda kurumsal bir uzlaşmanın sağlanamadığına işaret etmektedir $^{126}$. Bu durum, yukarıda daha önce değinilen bilimsel araştırma turizmini teşvik etmekte, araştırmacılar, bu konuda daha az kısıtlayıcı düzenlemeler içeren hukuk düzenlerinin sahip devletlere yönelmektedir ${ }^{127}$.

2004 yılı itibariyle, Avrupa Birliği'ne üye ülkeler bakımından konunun kabaca beş farklı biçimde düzenlenmekte olduğu dile getirilmiştir. Artan embriyonlardan kök hücre alınmasına koşullu olarak izin veren (Finlandiya, Yunanistan, Hollanda, İngiltere), bu embriyonlardan kök hücre alınmasını yasaklayan (Almanya, Avusturya, Danimarka, Fransa, İrlanda), embriyon ve kök hücre araştırmaları konusunda herhangi bir hukusal düzenleme bulunmayan (Belçika, İtalya, Lüksemburg, Portekiz - ki bunların bazılarında 2004 yılı itibariyle verilmiş kanun taslakları bulunmaktadır) kök hücre alınması amacıyla in vitro embriyon oluşturulmasına izin veren (İngiltere, Hollanda) ve gerek yasama yoluyla gerek Avrupa Konseyi İnsan Hakları ve Biyotıp Sözlemesi'nin onaylanması dolayısıyla kök hücre alınması ve bilimsel araştırma amaçlarıyla embriyon oluşturulmasını yasaklayan hukuk düzenleri bulunmaktadır. Bu sonuncular arasında ulusal mevzuatında koşullu olarak embriyonik kök hücre araştırmalarına izin veren Yunanistan, Finlandiya gibi ülkeler de vardır ${ }^{128}$.

${ }^{123}$ HALLIDAY, a.g.e., s. 40.

${ }^{124}$ HALLIDAY, a.g.e., s. 40.

${ }^{125}$ HALLIDAY, a.g.e., s. 40.

${ }^{126}$ Bkz. HALLIDAY, a.g.e., s. 41; ayrica MANUEL, C., HAIRON, D., AUQUIER, P., REVIRON, D., GIOCANTI, D., TERRIOU, P., PELLISSIER, V., SAN MARCO J.L., a.g.e., s. 56 .

${ }^{127}$ HALLIDAY, a.g.e., s. 41.

${ }^{128}$ HALLIDAY, a.g.e., s. $41,42$. 
Yine Avrupa ülkeleri arasında yapılan karşılaştırmalı bir çalışmada ${ }^{129}$ insan embriyonu bakımından anahatlarıyla üç farklı yoğunlukta hukuksal koruma sağlandığı tespit edilmiştir. En uç noktada yer alan koruma örneği İrlanda Cumhuriyetidir. İrlanda Cumhuriyeti Anayasası'nda insan embriyonu kişi gibi korunmaktadır. Alman Embriyon Koruma Kanunu'nda da insan embriyonunun menfaatine olmayan müdahalelerin yapılamayacağ yolunda düzenleme bulunmaktadır. Embriyonun hukuken bir deney malzemesi olarak kabul edilmesi diğer ucu oluşturmakla birlikte bu yönde bir düzenleme benimsemiş bir Avrupa ülkesi yoktur. Bu eğilimler dışında kalan düzenlemeler ise, orta yolu oluşturmaktadır. Bu noktada, insan onuru dolayısıyla insan embriyonuna, özellikle gelişim evreleri dikkate alınarak (örneğin İngiltere'deki ondört gün sınırı), bir değer atfedilmekle birlikte hukuken kişi olarak kabul edilmemekte ve kişi gibi korunmamaktadır. İnsan embriyonuna bu tarz koruma sağlanan ülkelerden İngiltere'nin hukuk düzeni, ayrıca embriyonik kök hücre araştırmalarına koşullu olarak izin vermektedir ${ }^{130}$.

İnsan embriyonuna atfedilen değer ve nitelik, korumanın evre ve yoğunluğunu belirleyen başlıca etkenlerdendir. İnsan embriyonuna verilecek zararı insan yaşamına verilen zarar olarak algılayanlar, tedavi amacıyla dahi embriyonal kök hücre çalışmalarına karşı çıkmaktadır ${ }^{131}$. İnsan onurunu hiçe sayan Nasyonal Sosyalist dönemin acı ve ağır mirası altında katı hukuksal düzenlemler kabul eden Almanya'da bilimsel araştırma amaciyla in vitro embriyon oluşturulması yasaklanmış olmakla birlikte 2002 yılına kadar, başka ülkelerden embriyonik kök hücre ithalatına izin verildiğini de belirtmek gerekir. 2002 yılında yapılan bir düzenleme ile bu ithalat başka ülkelerde de olsa insan embriyonlarının yok edilmesine yol açtığı için "kural olarak" yasaklanmış, ancak sıkı bir denetim altında istisnalara kapı aralanarak aslında ithalata kısmen de olsa devam edilmiştir ${ }^{132}$. Bu çerçevede, ithalat, ruhsata bağlanmıştır. Böyle bir ruhsat bulunmadan ithalat yapılması fiili suç olarak kabul edilerek üç yıla kadar hapis cezası ile cezalandırılmaktadır ${ }^{133}$. Alman Anayasa Mahkemesi, insan onurundan, sadece belli bir insanın onurunu değil insan türünün onurunu anlamaktadır. İnsan türünün ikame edilebilir nesneye dönüşmesi, araçsallaşması insan türünü tehdit eder. Embriyonun araştırma nesnesi haline gelmesi, embriyonun araçsallaştırılması ve yine insan türünün nesneleştirilmesidir, "şey" olarak kabul edilmesidir ${ }^{134}$.

${ }^{129}$ HALLIDAY, a.g.e., s. 42.

130 HALLIDAY, a.g.e., s. 42 ve 45; düzenlemeler bakımından ayrica MANUEL, C., HAIRON, D., AUQUIER, P., REVIRON, D., GIOCANTI, D., TERRIOU, P., PELLISSIER, V., SAN MARCO J.L., a.g.e., s. 60.

${ }^{131}$ ANDORNO, a.g.e., par. 22.

132 HALLIDAY, a.g.e., s. 43, 57 ve 60; MANUEL, C., HAIRON, D., AUQUIER, P., REVIRON, D., GIOCANTI, D., TERRIOU, P., PELLISSIER, V., SAN MARCO J.L., a.g.e., s. 56 .

${ }^{133}$ HALLIDAY, a.g.e., s. 60; Ayrica bkz. ROSENAU, a.g.e., s. 65 vd..

${ }^{134}$ HALLIDAY, a.g.e., s. 57. 
Bununla birlikte Alman hukukundaki bir çelişkiye dikkat çekilmesinde yarar vardır. İnsan embriyonuna sağlanan hukuki koruma mutlak değildir. Kürtaj ile ilgili ciddi tartışmaların yaşandığı bu ülkede, kadının sağlığı ve kişiliğinin özgürce gelişmesine ilişkin hakkına dayanarak kürtaj yaptırılabilmektedir. Yani in vivo oluşmuş insan embriyonu bazı koşulların varlığı halinde yok edilebilirken, in vitro embriyon sonlandırılarak tedavi amaçlı kök hücre elde edilmesi yasaktır. Buna göre, in vitro oluşturulmuş embriyon, in vivo oluşmuş embriyona göre yoğunlaştırılmış bir hukuki korumadan yararlanmaktadır ${ }^{135}$. Öte yandan yine Almanya'da in vitro oluşturulmuş fazla embriyonların imha edilmesi kabul edilmiştir. Nasyonal Sosyalist "araştırma tekniklerinin" etkisiyle Almanya, bilimsel çalışma alanında zarar veremediği fazla embriyonları, herhalde zaten imha etmek yoluna gitmektedir ${ }^{136}$.

Gerçekten, insan klonlaması dışında Alzheimer ya da Parkinson hastalıklarının tedavisi amacıyla embriyonik kök hücre çalışma ve uygulamalarının 18. madde karşısındaki durumunun berraklaştırılması gerekmektedir. Terapötik ya da tedavi amaçlı klonlama ile insan klonlanması arasında temel etik fark bulunmaktadır. Tedavi amaçlı embriyonik kök hücre çalışmalarının geleceği bakımından bu maddenin yorumu özel öneme sahiptir. Sözleşme'nin 18. maddesi dışında da konu tartış1lmış, tedavi amaçlı embriyonal kök hücre çalışmalarının yasaklanmaması gerektiği savunulmuştur ${ }^{137}$. Bu tür çalışmaların koşula bağlı olarak yürütülebildiği Hollanda, insan klonlama yasağına ilişkin Sözleşme'ye ek protokolü onaylarken insan deyiminden sadece sağ ve tamam doğmuş kimseleri yani hukuki anlamda kişileri anladığını beyan etmiştir ${ }^{138}$. Hollanda, böylece terapötik embriyonik kök hücre çalışmalarını, insan klonlama yasağı dışında kabul etmiştir.

Türk hukukunun 2004 yılından beri parçası olmasına karşın, uzunca bir süre Sözleşme'nin mevcudiyetinin ve doğrudan etkisinin farkına varılmamış, daha sonra 2005 Eylül ayında yayınlanarak valiliklere gönderilen Genelge ile embriyonik kök hücre çalışmaları durdurulmuştur. Kanımızca Genelge ile aslında zaten mevcut olan hukuksal durum tekrar ilan edilmiştir. Sözleşme'ye taraf olunması dolayısıyla embriyonik kök hücre çalışmalarına ilişkin yasaklayıcı hükümlerin Türk hukuku ve bilim yaşamı bakımından da sonuç doğuracağı açıktır.

Avrupa Birliği aygıtları içinde Avrupa Parlamentosu, 2001 yılında, Fiori raporu olarak bilinen ve terapötik klonlamanın yasaklanmasını öngören

\footnotetext{
${ }^{135}$ HALLIDAY, a.g.e., s. 58, 59.

${ }^{136}$ HALLIDAY, a.g.e., s. 59.

${ }^{137}$ ANDORNO, a.g.e., par. 22

${ }^{138}$ PATTINSON, a.g.e., s. 301; HALLIDAY, a.g.e., s. 53; BOSTYN, S.J.R., "The Prodigal Son: The Relationship between Patent Law and Health Care", Medical Law Review, 11, Spring 2003, s. 94 .
} 
bir metni büyük bir çoğunluk ile reddetmiştir. Bununla birlikte Avrupa Komisyonu nezdinde yürütülen çeşitli grup çalışmalarında terapötik klonlamanın yasaklanmasıyla birlikte yedek embriyonlar üzerinde embriyonik kök hücre çalışmalarının yapılmasını öneren raporlar hazırlanmıştır ${ }^{139}$.

$\mathrm{Bu}$ tür yasaklar, Sözleşme ile ortadan kaldırılmak istenen in vitro turizmi daha da teşvik edecektir. Bununla da kalmayacak, bu tür bir "üreme seyahatine" çıkmak için mali gücü bulunmayanlar bakımından da büyük bir haksızlık söz konusu olacaktır. Elektif kürtajın yasal olmadığ 1 dönemdeki hukuksal düzenlemelerin varlıklı olmayan hastalar aleyhine bir durum yarattığı günler hatırlardadır. Şimdi benzer bir durumla, üreme tıbbı ve bazı hastalıkların tedavisinde karşılaşılması mümkündür. Bunun yanı sıra düzenleme farklılıkları bilim insanları arasında da adaletsizliklere yol açacak, bazı ülkelerde yasaklar bilimsel araştırmayı engellerken diğerlerinde serbesti egemen olacaktır ${ }^{140}$.

\section{e. Nakil Amaçlarıyla Canlı Vericilerden Organ ve Doku Alınması ve Ticaret Yasağı}

Yaşayan kimselerden nakil amaçlarıyla organ ve doku alınmasına ilişkin temel ilkelere Sözleşme'nin 19 ve 20. maddelerinde yer verilmiştir. 19. maddede, yaşayan kimselerden organ ya da doku alınabilmesi için bunun bir anlamda son çare olması aranmaktadır. Ölmüş kimseden organ ya da doku naklinin mümkün bulunmadığı ya da benzer etkinlikte bir başka tedavi yöntemi olmadığı durumlarda yaşayan kimseden organ ya da doku nakline olanak tanınmaktadır.

20. maddede ise rıza yeteneği bulunmayanlardan organ ya da doku alınamaması kural olarak kabul edilmekle birlikte, aynı maddenin ikinci fıkrasında bunun istisnası ve bu istisnaya ilişkin koşullara yer verilmiştî ${ }^{141}$. Türkiye Cumhuriyeti istisnai de olsa özellikle küçüklerden organ alınmasını mutlak anlamda yasakladığından bu maddeye çekince koymuştur ${ }^{142}$.

Sözleşme'de kadavradan organ ve doku alınması konusunda herhangi bir hüküm bulunmamaktadır. Bu eksik, 24 Ocak 2002 tarihli İnsan Kaynaklı Organ ve Doku Nakli başlıklı Ek Protokol ile giderilmiştir ${ }^{143}$.

Sözleşme'nin 21. ve 22. maddelerinde insan vücudundan alınmış parçalara ilişkin ticari kazanç yasağı ve bu parçalar üzerinde tasarruf usulü

${ }^{139}$ SCHOTSMANS, a.g.e., par. 27.

140 MANUEL, C., HAIRON, D., AUQUIER, P., REVIRON, D., GIOCANTI, D., TERRIOU, P., PELLISSIER, V., SAN MARCO J.L., a.g.e., s. 63, 64.

${ }^{141}$ MANUEL, C., HAIRON, D., AUQUIER, P., REVIRON, D., GIOCANTI, D., TERRIOU, P., PELLISSIER, V., SAN MARCO J.L., a.g.e., s. 58, 59.

${ }^{142}$ PICIOCCHI, a.g.e., s. 4.

${ }^{143}$ SCHOTSMANS, a.g.e., par. 28. 
düzenlenmektedir. 21. maddede "Insan vücudu ve onun parçalarl, bu nitelikleri dolayısıyla, ticari kazanç sağlanmasına konu olmayacaktır" hükmüne yer verilmiş, 22. maddede ise, "Bir müdahale sirasinda insan vücudunun herhangi bir parçası alındığında, çıkarılan parça yalnızca uygun bilgi verme ve muvafakat alma usullerine uyulduğu takdirde, çıarılma amacından başka bir amaç için saklanabilir ve kullanılabilir" denmekle bu parçaların kullanılmasına ilişkin temel kurallar belirlenmiştir. Hükmün önemli taraflarından biri organ ve doku nakline ilişkin müdahalelerinden ticari kazanç elde edilmesinin yasaklanmasıdır ${ }^{144}$.

Özellikle "organ ticareti" ile kamuoyunun gündemini işgal eden bu hassas konu bakımından, söz konusu 21. maddenin yanı sıra UNESCO Bildirgesi'nin 4. maddesinde de benzeri yasak dile getirilmiş, Avrupa Birliği bünyesinde de bu tür ticari kazançla mücadele konusunda önlemler alınması çağrıları sıkça vurgulanmıştır. Yine ulusal hukuk düzenlerinde de bu yönde hükümlere yer verilmiştir ${ }^{145}$. Türk hukuk düzeninde, özel hukuk ve kamu hukuku alanlarında bu tür yasağa yer verilmiş, organ ve doku ticareti 5237 sayılı yeni Türk Ceza Kanunu'nun 91. maddesinde suç olarak tanımlanarak cezalandırmak yoluna gidilmiştir.

Sözleşme hükümlerinden önce konu esasen, 2238 sayılı Organ ve Doku Alınması, Saklanması, Aşılanması ve Nakli Hakkında Kanun'da düzenlenmişti. Bugün de yürürlükte olan bu kanunun ceza hükümlerine ek olarak yeni TCK ile de organ ve doku nakli alanına ilişkin cezai düzenlenmeler getirildiği görülmektedir. Ceza kanunlarının biribirini izlemesi bakımından yeni TCK, 2238 sayılı Kanun'a göre sonraki kanun konumundadır. Bu noktada 2238 sayılı Kanun'daki organ ve doku ticareti suçlarına ilişkin kimi hükümlerin ilga olduğu düşünülmektedirr ${ }^{146}$.

Gerçekten de, organ ve doku ticareti suçu yeni TCK'nun 91. maddesinde düzenlenmekle artık, hukuken geçerli rıza olmaksızın kişiden organ alan, hukuka aykırı olarak ölüden organ ve doku alanlar ile organ veya doku satın alanların, satanların ve satılmasına aracılık edenlerin TCK'na göre cezalandırıldıklarını kabul etmek gerekir. Bununla birlikte yeni TCK'nda düzenlenmeyen suç tanımları ve organ ve doku nakline ilişkin genel hükümler bakımından 2238 sayılı Kanun'un dikkate alınması zorunludur. $\mathrm{Bu}$ çerçevede küçüklerin ve diğer rıza yeteneği bulunmayanların hukuken geçersiz rıza beyanlarına dayanarak organ alınmasını yasaklayan 15. maddesi hükmü varlığını koruyacaktır.

\footnotetext{
${ }^{144}$ SCHOTSMANS, a.g.e., par. 29.

${ }^{145}$ McHALE, a.g.e., s. 134.

${ }^{146}$ HAKERİ, Hakan, Sorularla Ceza Hukuku, Ankara, Türkiye Barolar Birliği Yayını, 2005, s. 169.
} 


\section{SONUÇ}

Anayasa'nın 90. maddesi uyarınca Türk hukuk düzeninin bir parçası durumuna gelen Avrupa Konseyi İnsan Hakları ve Biyotıp Sözleşmesi, biyoloji ve tıbbın uygulanmasına rehberlik eden temel bazı biyoetik ilkeleri, pozitif hukukun içine yerleştirmiştir. Sözleşme, bu alandaki ilk bağlayıcı insan hakları metnidir, ve bu metin ile biyoloji ile tıbbın uygulanması konusu bir insan hakları konusu haline getirilmiştir.

Farklı ülke ve farklı kültürlerin, hazırlık çalışmalarına katkı sağlamış olması oydaşmayı güçleştirmiş, bazı muğlak ifadelerin kullanılmasına yol açmış ise de, İnsan Hakları Evrensel Bildirgesi örneğinde olduğu üzere, geniş bir katılım ile oluşturulan belgelerin etkinliği dikkate alındığında bu farklılıkların ortak bir dile ulaşılmasında olumlu katkıları bulunacağ 1 düşünülmelidir.

Sözleşme'nin herşeyden önce bir hukuk belgesi olduğu unutulmamalıdır. Bir etik bildirge değil, bağlayıcı bir hukuk belgesi söz konusudur. Biyotıp alanına uygulanan etik kurallar hukuk belgesinin içeriğine girmiştir ${ }^{147}$. Ancak metin, gerçekten de bir hukuk belgesidir. Hukuk ve etik arasında kimi zaman ihtilaflar olabilir. İhtilaflı konular, esasen yasama organındaki çoğunluğun oyları doğrultusunda çözülmektedir. Pozitif hukuk çokluk, çoğunluğun iradesiyken etik farklı kaynaklara sahiptir ${ }^{148}$. Etik ilkelerin doğrudan hukuk kaynağı olarak kabul edilmemesi, kaynağını etikte bulan kuralların hukuk kuralı haline dönüştürülmesi, kodifikasyona dayalı Kita Avrupası hukuk düzeni geleneğinin bir sonucudur ${ }^{149}$. Bu çerçevede, Sözleşme'nin biyoloji ve tıbbın uygulanmasına ilişkin temel ve doğrudan uygulanma özelliğine sahip bir uluslararası insan hakları "kodu" olarak kabul edilmesi gerektiği açıktır.

Hukukumuzda, Sözleşme ile korunan varlık ve menfaatleri teminat altına alan çeşitli düzenlemeler bulunmaktadır. Bu çerçevede, hukukumuzun çeşitli dallarında ve bu arada ceza hukuku bünyesinde, kimi temel Sözleşme hükümlerinin de müeyyidesini oluşturacak düzenlemeler bulunmaktadır. Yeni Türk Ceza Kanunu'nun özel yaşamın gizliliği, kişisel bilgilerin korunmasına yönelik hükümleri, insan ve çocuk üzerinde hukuka aykırı deneyi yasaklayan maddeleri ile organ ve doku ticareti suçuna ilişkin düzenlemeleri, bu ceza kuralları arasında dikkat çekenlerdir. Bunun yanı sıra genel hükümlerden hareketle de Sözleşme hükümlerine uyulmasının sağlanması mümkündür.

Tüm olumlu yanlarına karşın, bilimsel araştırmalara ilişkin kısıtlayıcı kimi hükümleriyle Sözleşme, ciddi eleştiriler ile de karşılaşmaktadır. Biyoloji ve tıbbın uygulanmasında bir ortak anlayış oluşturmak amacıyla

\footnotetext{
${ }^{147}$ De WACHTER, a.g.e., s. 22; SCHOTSMANS, a.g.e., par. 22.

${ }^{148}$ PENNINGS, a.g.e., s. 2690.

${ }^{149}$ HONNEFELDER, a.g.e., par. 8.
} 
hazırlanan Sözleşme'nin, özellikle tüpte embriyonlar üzerinde bilimsel araştırmaya ilişkin kısıtlayıcı hükümleri, bilimsel araştırmaların engelleneceği kaygısını taşıyan birçok Avrupa ülkesinin Sözleşme'yi onaylamamasına yol açmıştır. Bu nedenle, Sözleşme'ye taraf ülkelerin sıkı hukuksal rejimlerinden, görece serbest düzenlere bilim insanı ve hasta göçü devam edecektir. Türkiye bakımından da, tıbbi etkinliği ve etik yönü tamamen tartışmalı olmakla birlikte embriyonik kök hücre çalışmalarını sürdürmek isteyecek bilim insanlarının görece serbest hukuk iklimlerine göç etmesi olasılığı doğmuştur. Benzer bir göçün, yeni tedavi tekniklerinden yararlanmayı umut eden hastalar bakımından da yaşanabileceğini söylemek kehanet sayılmamalıdır.

Öte yandan, Sözleşme'ye, Avrupa Konseyi'ne yeni üye olan ülkelerin hemen tümü katılmıştır. Bir yazara göre, bu ülkeler, ne kadar Avrupalı olduklarını göstermek amacıyla Sözleşme'yi çabucak onaylamışlardır. Bununla birlikte eski üyeler arasında kuşku ve kaygılar varlığını korumaktadır $^{150}$.

\footnotetext{
${ }^{150}$ PENNINGS, a.g.e., s. 2693.
} 


\section{KAYNAKÇA}

ANDORNO, Roberto. Biomedicine and international human rights law: in search of global consensus. Bulletin of World Health Organization. Vol. 80, n. 12, Geneva, 2002. http://www.scielosp.org/scielo. (01.11.2005)

BOSTYN, S.J.R.. The Prodigal Son: The Relationship Between Patent Law and Patent Law and Health Care. Medical Law Review. No. 11, Spring 2003. Oxford University Press, ss. 67-120.

ERMAN, Barış. Ceza Hukukunda Tıbbi Müdahalelerin Hukuka Uygunluğu. Ankara. Seçkin, 2003.

GUNNING, Jennifer. Article 18 of the European Biomedicine Convention: "What Impact on Assisted Reproduction?" European Journal of Health Law. No. 6, 1999. Kluwer Law International, ss. 165-171.

HAKERİ, Hakan. Sorularla Ceza Hukuku. Ankara. Türkiye Barolar Birliği Yayını, 2005.

HALLIDAY, Samantha. A Comparative Approach to the Regulation of Human Embryonic Stem Cell Research in Europe. Medical Law Review. No. 12, Spring 2004, Oxford University Press, ss. 40-69.

HARRIS, John (ed.). Bioethics. Oxford Readings in Philosophy. Oxford University Press, 2004.

HONNEFELDER, Ludger. Bioethics and Human Genetics: Consensus Formation in Europe. Philosophisches Seminar der Universität Bonn, Lehr-und Forschungsbereich II.

JOHNSTON, Carolyn -Jane KAYE. Does the Biobank Have a Legal Obligation to Feedback Individual Findings to Participants? Medical Law Review. No. 12, Autumn 2004, Oxford University Press, ss. 239267.

KATOĞLU, Tuğrul. "Hekimin Cezai Sorumluluğu”. Doğum Hekimliği Maternal-Fetal Tıp'ta Etik ve Yasal Boyut. M. Sinan BEKSAÇ, Şebnem AKİPEK, Tuğrul KATOĞLU, Zarife ŞENOCAK, Mehmet Ali ŞUĞLE. Ankara. Medical Network, 2004.

KNOPPERS, Bartha M. - Rosario M. ISASI. Regulatory Approaches to Reproductive Genetic Testing. Human Reproduction. Vol. 19. No. 12, 2004, ss. 2695-2701.

MANUEL, C.; D. HAIRION, P. AUQUIER, D. REVIRON, D. GIOCANTI, P. TERRIOU, V.PELISSIER, J.L. SAN MARCO. "Is the Legislation of European States in Keeping with the Recent Convention on Human Rights and Biomedicine?" European Journal of Health Law. No. 6, 1999. Kluwer Law International, ss. 55-69. 
McHALE, J.V.. Regulating Genetic Databases: Some Legal and Ethical Issues. Medical Law Review. No. 12, Spring 2004. Oxford University Press, ss. 70-96.

NYS, Herman. Patients Rights in a European Health Care Market. Paper prepared for delivery at the Conference on European Integration and health Care Systems: A Challenge for Social Policy. 7-8 December 2001.

ÖZGENÇ, İzzet. Gerekçeli Türk Ceza Kanunu. Ankara. Seçkin, 2004.

ÖZSUNAY, Ergun. "Alman ve Türk Hukuklarında Hekimin Hastayı Aydınlatma Ödevi ve İstisnaları". Sorumluluk Hukukundaki Yeni Gelişmeler V. Sempozyumu, Türk Hukukunda Hekimin Hukuki ve Cezai Sorumluluğu. MHAUM. Ankara 12/13 Mart, 1982, İstanbul, 1983.

PATTINSON, Shaun D.. Reproductive Cloning: Can Cloning Harm the Clone? Medical Law Review. No. 10, Autumn 2002. Oxford University Press, ss. 295-307.

PENNINGS, Guido. Legal Harmonization and reproductive tourism in Europe. Human Reproduction. Vol. 19. No. 12, 2004, ss. 2689-2694.

PICIOCCHI, Cinzia. La Convenzione di Oviedo sui diritti dell'uomo e la biomedicina: Verso una bioethica europea? Diritto pubblico ed europeo. III, 2001. Rapport explicatif à la Convention pour la protection des droits de l'Homme et de la dignité de l'être humain à l'égard des applications de la biologie et de la médecine, http://infodoc.inserm.fr/ethique/Ethique.nsf

ROSENAU, Henning. "Yeniden canlı Üretimi, Tedavi Edici Klonlama Tartışmaları ve Alman Kök Hücre Kanunu". Çev. Hakan Hakeri. Karşılaştırmalı Güncel Ceza Hukuku Serisi 2. Tıp ve Ceza Hukuku. Ankara. Seçkin, 2004, ss. 43-80.

SANTANIELLO, Giuseppe. Ricerca genetica e tutela della persona. http://www.interlex.it/675/santaniello2.htm (09.11.2005)

SCHOTSMANS, Paul T.. Integration of Bioethical Principles and requirements into European Union Statues Regulations and Policies. Acta Bioethica. Vol. 11. No. 1, 2005. http://www.scielo.cl/scielo (01.11.2005)

SKENE, Loane. Patient's Rights or Family Responsabilities? Two Approaches to Genetic Testing. Medical Law Review. No. 6, Spring 1998. Oxford University Press, ss. 1-41.

TEZCAN, Durmuş; Mustafa Ruhan ERDEM; Murat ÖNOK. Teorik ve Pratik Ceza Özel Hukuku. Ankara. Seçkin, 2006. 
de WACHTER, Maurice A.M.. The European Convention on Bioethics. Hastings Center Report. January-February 1997, ss. 13-23.

WINTER, Stephan F.. The Cornerstones for a Prohibition of Cloning Human Beings laid down in the Convention on Human Rights and Biomedicine. European Journal of Health Law. No. 4, 1997. Kluwer Law International, ss. 73-77.

YENERER ÇAKMUT, Özlem. Tıbbi Müdahaleye Rızanın Ceza Hukuku Açısından İncelenmesi. İstanbul. Legal, 2003. 